\title{
The soil N cycle: new insights and key challenges
}

\author{
J. W. van Groenigen ${ }^{1}$, D. Huygens ${ }^{2,3,4}$, P. Boeckx ${ }^{2}$, Th. W. Kuyper ${ }^{1}$, I. M. Lubbers ${ }^{1}$, T. Rütting ${ }^{5}$, and \\ P. M. Groffman \\ ${ }^{1}$ Department of Soil Quality, Wageningen University, P.O. Box 47, 6700AA Wageningen, the Netherlands \\ ${ }^{2}$ Isotope Bioscience Laboratory (ISOFYS), Faculty of Bioscience Engineering, Ghent University, \\ Coupure Links 653, 9000 Ghent, Belgium \\ ${ }^{3}$ Instituto Multidisciplinario de Biología Vegetal - IMBIV, Consejo Nacional de Investigaciones Científicas y \\ Técnicas de Argentina, Universidad Nacional de Córdoba, Casilla de Correo 495, 5000 Córdoba, Argentina \\ ${ }^{4}$ Institute of Agricultural Engineering and Soil Science, Faculty of Agricultural Sciences, \\ Universidad Austral de Chile, Valdivia, Chile \\ ${ }^{5}$ Department of Earth Sciences, University of Gothenburg, Box 460, 40530 Gothenburg, Sweden \\ ${ }^{6}$ Cary Institute of Ecosystem Studies, 2801 Sharon Turnpike, P.O. Box AB, Millbrook, NY 12545-0129, USA
}

Correspondence to: J. W. van Groenigen (janwillem.vangroenigen@wur.nl)

Received: 7 October 2014 - Published in SOIL Discuss.: 28 October 2014

Revised: - - Accepted: 2 March 2015 - Published: 11 March 2015

\begin{abstract}
The study of soil $\mathrm{N}$ cycling processes has been, is, and will be at the centre of attention in soil science research. The importance of $\mathrm{N}$ as a nutrient for all biota; the ever-increasing rates of its anthropogenic input in terrestrial (agro)ecosystems; its resultant losses to the environment; and the complexity of the biological, physical, and chemical factors that regulate $\mathrm{N}$ cycling processes all contribute to the necessity of further understanding, measuring, and altering the soil $\mathrm{N}$ cycle. Here, we review important insights with respect to the soil $\mathrm{N}$ cycle that have been made over the last decade, and present a personal view on the key challenges of future research. We identify three key challenges with respect to basic $\mathrm{N}$ cycling processes producing gaseous emissions:
\end{abstract}

1. quantifying the importance of nitrifier denitrification and its main controlling factors;

2. characterizing the greenhouse gas mitigation potential and microbiological basis for $\mathrm{N}_{2} \mathrm{O}$ consumption;

3. characterizing hotspots and hot moments of denitrification

Furthermore, we identified a key challenge with respect to modelling:

1. disentangling gross $\mathrm{N}$ transformation rates using advanced ${ }^{15} \mathrm{~N} /{ }^{18} \mathrm{O}$ tracing models

Finally, we propose four key challenges related to how ecological interactions control $\mathrm{N}$ cycling processes:

1. linking functional diversity of soil fauna to $\mathrm{N}$ cycling processes beyond mineralization;

2. determining the functional relationship between root traits and soil $\mathrm{N}$ cycling;

3. characterizing the control that different types of mycorrhizal symbioses exert on $\mathrm{N}$ cycling;

4. quantifying the contribution of non-symbiotic pathways to total $\mathrm{N}$ fixation fluxes in natural systems

We postulate that addressing these challenges will constitute a comprehensive research agenda with respect to the $\mathrm{N}$ cycle for the next decade. Such an agenda would help us to meet future challenges on food and energy security, biodiversity conservation, water and air quality, and climate stability. 


\section{Introduction}

Humankind's relationship with soil nitrogen $(\mathrm{N})$ has been a long and troubled one. For most of agricultural history, farmers have struggled to maintain soil fertility levels in their fields, relying mostly on biological N fixation (BNF), decomposition of soil organic matter and redistribution of organic materials to provide $\mathrm{N}$ to their crops. With the onset of largescale application of mineral fertilizers in the 1950s, the main focus in large parts of the world has gradually shifted towards minimizing harmful losses to the environment resulting from the large amounts of $\mathrm{N}$ entering the global food production system (Galloway et al., 2013).

The history of research on the soil $\mathrm{N}$ cycle reflects this shift. The study of $\mathrm{N}$ cycling processes started after Carl Sprengel's discovery (popularized by Justus Von Liebig) of the importance of $\mathrm{N}$ as a factor limiting the growth of crop plants in the mid-19th century (Gorham, 1991). More than 150 years of research has demonstrated that this element limits ecosystem productivity over large areas of the globe and is highly sensitive to changes in temperature, precipitation, atmospheric $\mathrm{CO}_{2}$, and disturbance regimes (Galloway et al., 2008). Since the 1960 s, following the realization that excess $\mathrm{N}$ has negative effects on water, air, and ecosystem and human health (Compton et al., 2011; Davidson et al., 2012), the study of the $\mathrm{N}$ cycle has intensified, focusing on $\mathrm{N}$ loss pathways next to the more traditional study topics such as plant $\mathrm{N}$ uptake. Most recently, the realization that the response of ecosystems to global environmental change would to a large extent depend on $\mathrm{N}$ dynamics (Van Groenigen et al., 2006; Luo et al., 2011) has generated further interest in the soil $\mathrm{N}$ cycle.

The need for more information on soil $\mathrm{N}$ cycling process rates is highlighted by large amounts of "missing N" that dominate $\mathrm{N}$ balances at all scales. Inputs of $\mathrm{N}$ through fertilization, BNF, atmospheric deposition, and human and animal waste have been found to be substantially higher than hydrological outputs of $\mathrm{N}$ in many studies and at many scales (Howarth et al., 1996; Boyer et al., 2002; Groffman, 2008). There is much uncertainty about the fate of this excess $\mathrm{N}$ (Van Breemen et al., 2002). Is it stored in soils or vegetation? Is it converted to gas, and if so, in which forms? This uncertainty is particularly compelling in agricultural systems which receive high rates of $\mathrm{N}$ input. The air and water quality impacts of the $\mathrm{N}$ exports in these systems are cause for great concern (Davidson et al., 2012). In other ecosystems, on the other hand, there is concern about missing $\mathrm{N}$ inputs. Unexplained accumulation of $\mathrm{N}$ in aggrading forests (Bernal et al., 2012; Yanai et al., 2013) and in vegetation exposed to elevated levels of atmospheric $\mathrm{CO}_{2}$ (Zak et al., 2003; Finzi et al., 2007) suggests unmeasured inputs of $\mathrm{N}$ via BNF (Cleveland et al., 2010) or uncharacterized mechanisms of soil $\mathrm{N}$ turnover and mineralization (Drake et al., 2011; Phillips et al., 2011, 2012).
A particularly pressing need in $\mathrm{N}$ cycling research has been in the area of gaseous emissions, especially of those that contribute to global warming. The role of soil biogeochemists is to generate field data on terrestrial greenhouse emissions, but high uncertainties in soil $\mathrm{N}_{2} \mathrm{O}$ and $\mathrm{N}_{2}$ budgets still exist. Much of this uncertainty arises from a lack of information about the importance of the variety of $\mathrm{N}$ gas forming processes occurring in the soil and the methodological constraints on flux measurements (Ambus et al., 2006). Evidence is emerging that processes other than nitrification and denitrification are far more important than previously assumed for gaseous $\mathrm{N}$ production from soils. Processes such as nitrifier denitrification (Wrage et al., 2001), in situ $\mathrm{N}_{2} \mathrm{O}$ reduction (Schlesinger, 2013), anammox (Mulder et al., 1995), Feammox (Sawayama, 2006), dissimilatory nitrate reduction to ammonium (DNRA) (Tiedje, 1988), and co-denitrification (Spott et al., 2011) have all been hypothesized to play a role in the gaseous $\mathrm{N}$ cycle. Novel and fascinating efforts to extract DNA and RNA and to define microbial communities have recently produced new information on the agents that carry out many of these processes (Isobe and Ohte, 2014). However, information on process rates and their dynamics in response to a myriad of environmental factors are clearly lacking. Such information is vital however, as gene presence is a proxy for potential activity, but is not final proof of the occurrence of ecologically significant process rates.

One of the reasons that it has been so difficult to quantify and characterize $\mathrm{N}$ cycling processes is that they are to a large extent controlled by indirect, biotic interactions. It is becoming increasingly clear that ecological interactions play a major role in the terrestrial $\mathrm{N}$ cycle. The realization that global change may alter the nature and timing of biotic interactions and thereby their effects on the $\mathrm{N}$ cycle only increases the need for their study (Díaz et al., 1998; Chapin et al., 2000). In some ecosystems, $\mathrm{N}$ inputs to terrestrial ecosystems are dominantly mediated by mutualistic associations between plants and specific $\mathrm{N}$-fixing microbial groups (Batterman et al., 2013a). More generally, plant species have an overarching impact on soil $\mathrm{N}$ cycling by directly mediating energy and material fluxes to soil microbial communities and/or by altering abiotic conditions that regulate microbial activity. For example, the type of mycorrhizal fungi that colonizes the plant root has been shown to correlate with organic $\mathrm{N}$ depolymerisation as fungal groups produce a specific set of enzymes. Also, soil fauna have both a direct and indirect role in the soil $\mathrm{N}$ cycle as grazing may strongly affect microbial $\mathrm{N}$ release as well as alter soil physical properties. All these ecological interactions have a high degree of specificity and sensitivity to global change, which increases the probability that a change in plant, microbial, or faunal community composition will have cascading effects on the rest of the system and on the overall soil $\mathrm{N}$ cycle (Chapin et al., 2000).

Here, we review important insights with respect to the soil $\mathrm{N}$ cycle that have been made over the last decade and 


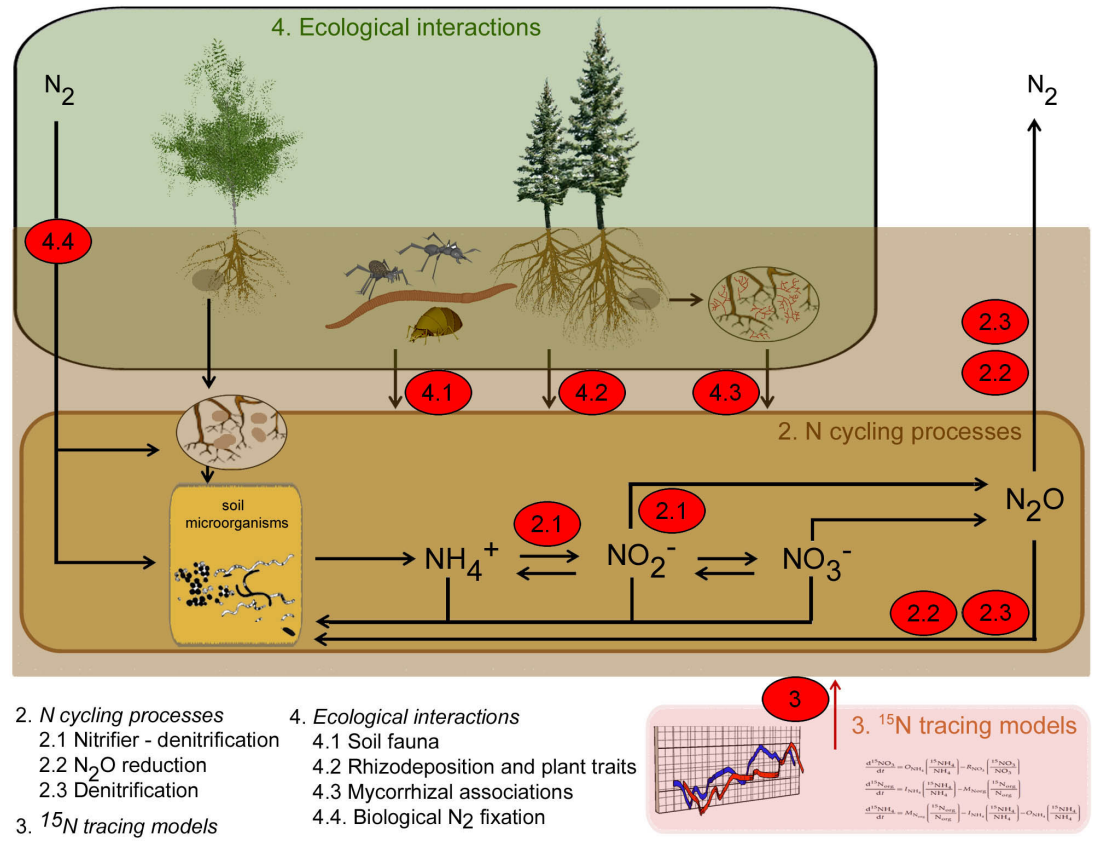

Figure 1. New insights and key challenges with respect to the soil $\mathrm{N}$ cycle, as identified in this paper. These include three $\mathrm{N}$ cycling processes (Sects. 2.1-2.3), a modelling challenge (Sect. 3), and four pathways through which ecological interactions might affect $\mathrm{N}$ cycling processes (Sects. 4.1-4.4).

present our view on the key challenges of future soil research (Fig. 1). The approach adopted in this paper is three-fold:

1. to identify and critically review specific $\mathrm{N}$ transformation pathways related to the production of $\mathrm{N}_{2} \mathrm{O}$ and $\mathrm{N}_{2}$. We focus on nitrifier denitrification (Sect. 2.1), which is a potentially important source of $\mathrm{N}_{2} \mathrm{O}$, and $\mathrm{N}_{2} \mathrm{O}$ reduction (Sect. 2.2), the important but little-understood final step of denitrification. We focus on these two processes as we believe that sufficient literature information is available to demonstrate that these processes are key unknowns with respect to the emission rates of gaseous $\mathrm{N}$ forms. Additionally, we discuss challenges with respect to measuring hotspots and hot moments of denitrification (Sect. 2.3);

2. to present methodological developments on ${ }^{15} \mathrm{~N}$ tracing models that should further aid studies on the production of gaseous $\mathrm{N}$ forms in soils (Sect. 3); and

3. to review mechanisms on how ecological interactions impact soil N cycling. Specifically, we focus on soil faunal effects (Sect. 4.1), plant root controls (Sect. 4.2), mycorrhizal symbioses (Sect. 4.3), and biological N fixation (Sect. 4.4). Although other nutrient cycles can have strong effects on all aspects of the $\mathrm{N}$ cycle (e.g. Baral et al., 2014), we consider stoichiometric relationships to be mostly outside the scope of this paper and do not exhaustively review them.
Although all authors agree with the contents of the final paper, some freedom has been given to express a somewhat personal view on developments within our respective fields of expertise (see Author Contributions). This paper is not meant as a comprehensive literature review of soil $\mathrm{N}$ cycling research in the past. Instead, we have tried to be judicious with respect to referencing older studies, only citing some key papers and focusing instead on more recent work. As such, we hope that our paper will spark discussion and inspire further research on the elusive aspect of soil $\mathrm{N}$ cycling.

\section{Emerging insights on gaseous nitrogenous emissions}

\subsection{Nitrifier denitrification}

The study of nitrifier denitrification as a significant biogeochemical $\mathrm{N}_{2} \mathrm{O}$-producing process in soils has been severely hampered by two persistent problems: one related to terminology, the other to methodology.

With respect to terminology, it took a landmark paper (Wrage et al., 2001) to clearly identify nitrifier denitrification as a distinct pathway for $\mathrm{N}_{2} \mathrm{O}$ production, as it was often confused or combined with two other $\mathrm{N}_{2} \mathrm{O}$ production pathways: nitrifier nitrification and nitrification coupled denitrification (which is actually a combination of two classical processes rather than a novel one: nitrifier nitrification followed by classical denitrification; Fig. 2). Nitrifier denitrification is the production of $\mathrm{N}_{2} \mathrm{O}$ by autotrophic ammonia-oxidizing bacte- 


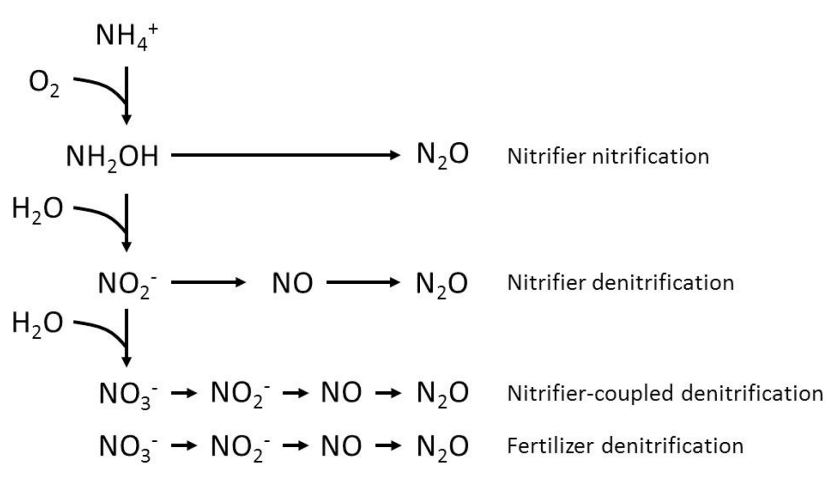

Figure 2. Different pathways of $\mathrm{N}_{2} \mathrm{O}$ production in soil. Classical nitrification by autotrophic bacteria or archaea (nitrifier nitrification); nitrifier denitrification by the same group of autotrophic bacteria; nitrification followed by denitrification (nitrification-coupled denitrification) and direct denitrification of applied nitrogen fertilizer (fertilizer denitrification). Reproduced from Kool et al. (2011a).

ria by reduction of $\mathrm{NO}_{2}^{-}$. The process is therefore carried out by the same organisms that can produce $\mathrm{N}_{2} \mathrm{O}$ through nitrification. However, the two $\mathrm{N}_{2} \mathrm{O}$ producing pathways are fundamentally different; during nitrification $\mathrm{N}_{2} \mathrm{O}$ is formed as a byproduct of a chemical process: the spontaneous oxidation of one of the intermediate $\mathrm{N}$ species (hydroxylamine). Nitrifier denitrification, on the other hand, is a stepwise reduction controlled by enzymes during which $\mathrm{N}_{2} \mathrm{O}$ is one of the intermediate products that might escape to the atmosphere. In fact, the enzymes responsible for this stepwise reduction during nitrifier denitrification are remarkably similar to those of canonical denitrification (possibly due to lateral gene transfer); they do not appear to differ phylogenetically from nitrite reductase $(\mathrm{NiR})$ and nitrous oxide reductase (NOR) found in denitrifying organisms (Casciotti and Ward, 2001; Garbeva et al., 2007).

Despite the similarity with classical denitrification, there are good reasons to assume that nitrifier denitrification is controlled by different factors and should therefore be considered as a distinct source of $\mathrm{N}_{2} \mathrm{O}$ emissions from soil. The main reason for this is that denitrifiers are heterotrophic, whereas ammonia-oxidizing bacteria are chemoautotrophic. It is not entirely clear yet why ammonia-oxidizing bacteria perform nitrifier denitrification. One hypothesis is that it is a response to $\mathrm{NO}_{2}^{-}$toxicity under marginally aerobic conditions (Shaw et al., 2006). Alternatively, the energetic gain from coupling $\mathrm{NH}_{4}^{+}$oxidization to $\mathrm{NO}_{2}^{-}$reduction is similar to that from using $\mathrm{O}_{2}$, making nitrifier denitrification energetically attractive under marginally aerobic conditions (Shaw et al., 2006).

The process was described by early pure culture studies in the 1960s and 1970s (Hooper, 1968; Ritchie and Nicholas, 1972). Since then, it has been reported several times (e.g. Poth and Focht, 1985; Schmidt et al., 2004), but always in pure cultures. Despite suggestions that nitrifier denitrifica- tion could be an important contributor to soil $\mathrm{N}_{2} \mathrm{O}$ emissions (Granli and Bøckman, 1994; Webster and Hopkins, 1996), and that conventional methods of "nitrification $\mathrm{N}_{2} \mathrm{O}$ " measurements such as ${ }^{15} \mathrm{~N}$ tracing or inhibition with $\mathrm{O}_{2}$ or acetylene might actually include nitrifier denitrification (Granli and Bøckman, 1994; Mosier et al., 1998), proof of its occurrence in actual soils has remained elusive.

The main challenge to evaluating the importance of nitrifier denitrification in soils is methodology. As the $\mathrm{N}$ in $\mathrm{N}_{2} \mathrm{O}$ produced from both nitrification and nitrifier denitrification originates from the same $\mathrm{NH}_{4}^{+}$pool, it is impossible to distinguish between these two processes with conventional ${ }^{15} \mathrm{~N}$ tracing methods (Stevens et al., 1997) alone. Methods using inhibition of specific steps of (de)nitrification were proposed as a method to quantify nitrifier denitrification (Webster and Hopkins, 1996), but a series of studies showed that inhibition was unreliable due to problems with effectiveness and selectivity (Tilsner et al., 2003; Beaumont et al., 2004; Wrage et al., 2004a, b).

Various efforts have been undertaken to employ advanced stable isotope analysis to determine the contribution of nitrifier denitrification as an $\mathrm{N}_{2} \mathrm{O}$ source. Sutka et al. (2006) suggested that the intramolecular distribution of ${ }^{15} \mathrm{~N}$ within the asymmetrical $\mathrm{N}_{2} \mathrm{O}$ molecule (site preference) might be employed. In pure culture studies, they showed that the site preference signature of nitrifier denitrification and denitrification differed significantly from that of classical nitrification (Sutka et al., 2006) and fungal denitrification (Ostrom and Ostrom, 2011). However, in a recent assessment Decock and Six (2013) concluded that huge challenges remain (related to process rates, heterogeneity, and unaccounted-for processes, among others) before such an analysis can be reliably applied to soils. They conclude that analysis of site preference will likely remain a qualitative indicator of mechanisms underlying $\mathrm{N}_{2} \mathrm{O}$ emissions, and recommend more studies to systematically characterize variations in site preference as a function of ecosystem, soil parameters, and biogeochemical processes. Such studies are currently being conducted (e.g. Koster et al., 2013; Lewicka-Szczebak et al., 2014; Yano et al., 2014).

Wrage et al. (2005) proposed an alternative method based on artificially enriched stable isotope tracing. They combined ${ }^{15} \mathrm{~N}$ with ${ }^{18} \mathrm{O}$ tracing to isolate nitrifier denitrification, utilizing the fact that all $\mathrm{O}$ in nitrifier-derived $\mathrm{N}_{2} \mathrm{O}$ originates from $\mathrm{O}_{2}$, but half of the $\mathrm{O}$ from nitrifier denitrification is derived from $\mathrm{H}_{2} \mathrm{O}$. However, their method, employing ${ }^{18} \mathrm{O}-$ enriched $\mathrm{H}_{2} \mathrm{O}$ as well as ${ }^{15} \mathrm{~N}-\mathrm{NO}_{3}^{-}$and ${ }^{15} \mathrm{~N}_{-} \mathrm{NH}_{4}^{+}$, did not take into account $\mathrm{O}$ exchange between $\mathrm{H}_{2} \mathrm{O}$ and intermediates of the (de)nitrification pathways (Kool et al., 2007, 2009). This exchange can be quantified using ${ }^{18} \mathrm{O}$-labelled $\mathrm{NO}_{3}^{-}$(Kool et al., 2010, 2011b). With the help of a revised method, Kool et al. (2011a) showed that nitrifier denitrification exceeded "classical nitrification" as a dominant source of $\mathrm{NH}_{4}^{+}$-derived $\mathrm{N}_{2} \mathrm{O}$ emission, and was a dominant path- 
way of total $\mathrm{N}_{2} \mathrm{O}$ production at low and intermediate soil moisture contents. Other studies using this method have confirmed that nitrifier denitrification was indeed the dominant pathway for $\mathrm{NH}_{4}^{+}$-derived $\mathrm{N}_{2} \mathrm{O}$ emissions (Zhu et al., 2013). With terminology established and a method developed, nitrifier denitrification is now ready to be studied in detail in soils. However, methodological constraints still exist, as the dual isotope method is elaborate and includes a relatively large number of assumptions.

\subsection{Nitrous oxide consumption}

Both net atmospheric and in situ $\mathrm{N}_{2} \mathrm{O}$ consumption occur in the soil, reducing both atmospheric lifetimes of $\mathrm{N}_{2} \mathrm{O}$ and net $\mathrm{N}_{2} \mathrm{O}$ effluxes. Consumption of $\mathrm{N}_{2} \mathrm{O}$ is enzymatically and energetically feasible. Net atmospheric consumption of $\mathrm{N}_{2} \mathrm{O}$ has been sporadically reported for several terrestrial ecosystems, but mostly for wetlands and peatlands. A recent review by Schlesinger (2013) reports a net $\mathrm{N}_{2} \mathrm{O}$ uptake range of $<1-207 \mu \mathrm{g} \mathrm{N} \mathrm{m}{ }^{-2} \mathrm{~h}^{-1}$, but almost all uptake fluxes fall between 1 and $10 \mu \mathrm{g} \mathrm{N}^{-2} \mathrm{~h}^{-1}$, with a median of $4 \mu \mathrm{g} \mathrm{N} \mathrm{m}^{-2} \mathrm{~h}^{-1}$. The latest IPCC report (Stocker et al., 2013) mentions a global surface $\mathrm{N}_{2} \mathrm{O}$ sink of $0-1 \mathrm{Tg} \mathrm{N} \mathrm{N}_{2} \mathrm{O}$ $\mathrm{Nyr}^{-1}$. Another recent review (Majumdar, 2013) reported in situ $\mathrm{N}_{2} \mathrm{O}$ consumption rates in rice fields ranging from 0.13-191 $\mu \mathrm{g} \mathrm{N} \mathrm{m}^{-2} \mathrm{~h}^{-1}$. For that purpose, Yang et al. (2011) developed an ${ }^{15} \mathrm{~N}_{2} \mathrm{O}$ isotope dilution method that allows for calculation of gross $\mathrm{N}_{2} \mathrm{O}$ production and consumption rates. These authors observed a relative $\mathrm{N}_{2} \mathrm{O}$ yield of 0.84 , indicating that $16 \%$ of the gross $\mathrm{N}_{2} \mathrm{O}$ production was consumed in situ. However, Well and Butterbach-Bahl (2013) question the validity of the latter experimental approach. Understanding the role of in situ $\mathrm{N}_{2} \mathrm{O}$ reduction for attenuation of the net soil $\mathrm{N}_{2} \mathrm{O}$ release warrants careful attention because of a recently identified microbial guild capable of $\mathrm{N}_{2} \mathrm{O}$ reduction (Sanford et al., 2012).

Based on recent evidence from the literature we have identified three possible routes for $\mathrm{N}_{2} \mathrm{O}$ consumption. First, in addition to the "typical" nitrous oxide reductase (nosZ I) that reduces $\mathrm{N}_{2} \mathrm{O}$ during denitrification, a recently identified microbial guild is suggested to mediate the soil $\mathrm{N}_{2} \mathrm{O}$ sink (Sanford et al., 2012; Jones et al., 2014). Newly discovered nondenitrifier, "atypical" $\mathrm{N}_{2} \mathrm{O}$ reductase (nosZ II) gene diversity and abundance potentially play a significant role in $\mathrm{N}_{2} \mathrm{O}$ consumption in soil. Orellana et al. (2014) indicated that atypical nosZ outnumbers typical nosZ in soil.

Second, some bacteria that perform dissimilatory nitrate reduction to ammonia (DNRA) are capable of $\mathrm{N}_{2} \mathrm{O}$ reduction to $\mathrm{N}_{2}$ as they carry a nos gene encoding for $\mathrm{N}_{2} \mathrm{O}$ reductase $\left(\mathrm{N}_{2} \mathrm{OR}\right)$ (Simon et al., 2004). Mania et al. (2014) indicated that, depending on the environmental conditions, these bacteria may reduce $\mathrm{N}_{2} \mathrm{O}$ that is provided by other bacteria or that they produced themselves as a by-product during DNRA.

Third, there is evidence that both direct assimilatory $\mathrm{N}_{2} \mathrm{O}$ fixation via nitrogenase (Vieten et al., 2008; Ishii et al., 2011;

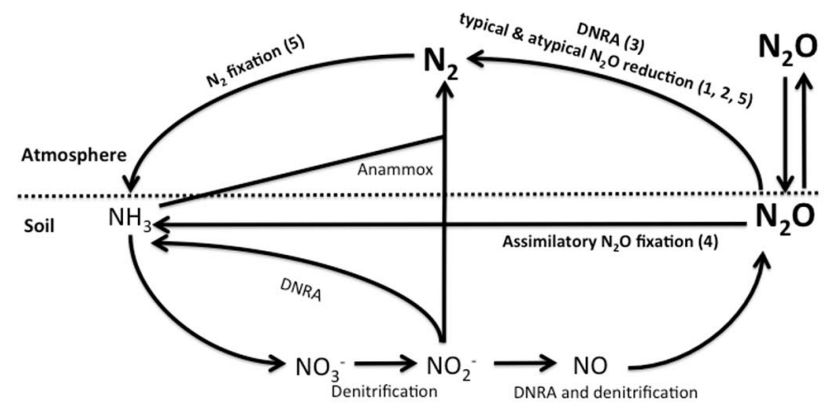

Figure 3. The $\mathrm{N}_{2} \mathrm{O}$ production and consumption network showing five pathways for $\mathrm{N}_{2} \mathrm{O}$ consumption. Dissimilatory $\mathrm{N}_{2} \mathrm{O}$ reduction to $\mathrm{N}_{2}$ via typical, denitrifier nosZ I (1); atypical, non-denitrifier nosZ II (2); dissimilatory $\mathrm{NO}_{3}^{-}$reduction to $\mathrm{NH}_{3}$ (DNRA) (3); direct assimilatory $\mathrm{N}_{2} \mathrm{O}$ fixation via nitrogenase to $\mathrm{NH}_{3}$ (4); and indirect assimilatory $\mathrm{N}_{2} \mathrm{O}$ fixation $\left(\mathrm{N}_{2} \mathrm{O}\right.$ reduction to $\mathrm{N}_{2}$ followed by $\mathrm{N}_{2}$ fixation) (5). Abiotic pathways that produce gaseous $\mathrm{N}$ (Feammox and chemo-denitrification) are not shown.

Farías et al., 2013) or indirect $\mathrm{N}_{2} \mathrm{O}$ fixation via a combination of $\mathrm{N}_{2} \mathrm{O}$ reduction and $\mathrm{N}_{2}$ fixation can account for $\mathrm{N}_{2} \mathrm{O}$ consumption. Itakura et al. (2013) showed that inoculation of soil grown with soybean with a non-genetically modified mutant of Bradyrhizobium japonicum with higher $\mathrm{N}_{2} \mathrm{O}$ reductase activity (nosZ++) reduced $\mathrm{N}_{2} \mathrm{O}$ emission. In farm-scale experiments on an Andosol, an $\mathrm{N}_{2} \mathrm{O}$ mitigation of ca. $55 \%$ was achieved with such inoculation. Desloover et al. (2014) identified a Pseudomonas stutzeri strain that was able to grow on $\mathrm{N}_{2} \mathrm{O}$ as the only source of $\mathrm{N}$ and electron acceptor. Pseudomonas stutzeri is known to possess both nitrogenase and nitrous oxide reductase (nosZ I) (Pomowski et al., 2011). A ${ }^{15} \mathrm{~N}$ labelling study showed that $\mathrm{N}_{2} \mathrm{O}$ is immobilized into microbial biomass via $\mathrm{N}_{2} \mathrm{O}$ reduction to $\mathrm{N}_{2}$ followed by reuptake of the released $\mathrm{N}_{2}$ and subsequent fixation into $\mathrm{NH}_{4}^{+}$ via nitrogenase (Desloover et al., 2014).

In conclusion, five possible pathways for $\mathrm{N}_{2} \mathrm{O}$ consumption have been identified (Fig. 3): (1) dissimilatory $\mathrm{N}_{2} \mathrm{O}$ reduction to $\mathrm{N}_{2}$ via typical, denitrifier nosZ I, (2) atypical, non-denitrifier nosZ II, (3) DNRA that produces $\mathrm{N}_{2} \mathrm{O}$ as a by-product, (4) direct assimilatory $\mathrm{N}_{2} \mathrm{O}$ fixation via nitrogenase to $\mathrm{NH}_{3}$, and (5) indirect assimilatory $\mathrm{N}_{2} \mathrm{O}$ fixation $\left(\mathrm{N}_{2} \mathrm{O}\right.$ reduction to $\mathrm{N}_{2}$ followed by $\mathrm{N}_{2}$ fixation). Clearly, $\mathrm{NO}_{3}^{-}$reduction in soil is handled by a network of actors (Kraft et al., 2011) and has a more modular character than the classical linear presentation of denitrifying enzymes suggests ( $\mathrm{Si}$ mon and Klotz, 2013). Moreover, a high degree of metabolic versatility is observed for many organisms; genes encoding for denitrification, DNRA, and atmospheric $\mathrm{N}$ fixation have, for instance, been found in a single bacterial species (Simon, 2002; Mania et al., 2014). Finally, Verbaendert et al. (2014) showed that molecular tools that have been developed to identify denitrifying bacteria are biased towards Gram-negative denitrifiers. Hence, we propose that the anal- 
ysis of expression of novel, recently discovered genes involved in $\mathrm{N}_{2} \mathrm{O}$ consumption in conjunction with quantification of $\mathrm{N}_{2} \mathrm{O}$ fluxes in various soil types is required to advance our understanding of microbial and physicochemical controls on $\mathrm{N}_{2} \mathrm{O}$ consumption, and ultimately to develop improved biogeochemical models of soil $\mathrm{N}_{2} \mathrm{O}$ sink function.

\subsection{Denitrification}

Denitrification, the anaerobic microbial conversion of the nitrate $\left(\mathrm{NO}_{3}^{-}\right)$and nitrite $\left(\mathrm{NO}_{2}^{-}\right)$to the gases nitric oxide $(\mathrm{NO})$, nitrous oxide $\left(\mathrm{N}_{2} \mathrm{O}\right)$, and dinitrogen $\left(\mathrm{N}_{2}\right)$ (Seitzinger et al., 2006; Groffman, 2012) is an extremely challenging process to measure. This process is of great interest because it can significantly reduce pools of reactive $\mathrm{N}$ (and thus productivity) in ecosystems and because $\mathrm{NO}_{3}^{-}, \mathrm{NO}$, and $\mathrm{N}_{2} \mathrm{O}$ cause diverse air and water pollution problems (Davidson et al., 2012). Denitrification is difficult to quantify because of problematic measurement techniques (especially for its end product $\mathrm{N}_{2}$ ), high spatial and temporal variability, and a lack of methods for scaling point measurements to larger areas (e.g. Groffman et al., 2006). A particular challenge is the fact that small areas (hotspots) and brief periods (hot moments) frequently account for a high percentage of $\mathrm{N}$ gas flux activity, and that it is increasingly recognized that denitrification is in many ways a modular rather than a singular process. This presents a variety of problems related to measurement, modelling, and scaling (Groffman et al., 2009). Global mass balance analyses (Seitzinger et al., 2006) suggest that the biggest global sink for anthropogenic $\mathrm{N}$ must be terrestrial denitrification, yet there are few direct measurements to support these results. Modelling efforts estimate that global $\mathrm{N}_{2}$ production from denitrification may increase from $96 \mathrm{Tg} \mathrm{yr}^{-1}$ in 2000 to $142 \mathrm{Tg} \mathrm{yr}^{-1}$ in 2050 due to increased $\mathrm{N}$ inputs in the global agricultural system (Bouwman et al., 2013). Questions about 'missing N' and denitrification are particularly dramatic and compelling in agricultural ecosystems, landscapes, and regions, where most industrially derived $\mathrm{N}$ is applied and the opportunity for large terrestrial denitrification fluxes exists.

Addressing the challenge of denitrification requires advances in three main areas: (1) improved methods for quantifying N gas fluxes (see also Sect. 2.2); (2) experimental designs that incorporate hotspot and hot moment phenomena; and (3) approaches for temporal and spatial scaling that account for hotspot and hot moment phenomena at multiple scales.

Denitrification has always been a challenging process to measure (Groffman et al., 2006), primarily due to the difficulty of quantifying the flux of $\mathrm{N}_{2}$ from soil against the high natural atmospheric background of this gas (Yang and Silver, 2012; Yang et al., 2014). Most denitrification methods therefore involve alteration of physical or chemical conditions through the use of inhibitors (e.g. acetylene) or amendments $\left(\right.$ e.g. $\left.{ }^{15} \mathrm{~N}\right)$ that produce inaccurate or unrealistic esti- mates of rates. However, there have been recent advances in methods for quantifying $\mathrm{N}_{2}$ flux and in isotope-based methods that provide area- and time-integrated denitrification estimates that are more relevant to ecosystem-scale questions.

Our understanding of the $\mathrm{N}_{2}$ flux associated with denitrification has been improved at least somewhat by the development of soil core-based gas recirculation systems that involve replacement of the natural soil $\mathrm{N}_{2} / \mathrm{O}_{2}$ atmosphere with a $\mathrm{He} / \mathrm{O}_{2}$ atmosphere, followed by direct measurement of $\mathrm{N}_{2}$ and $\mathrm{N}_{2} \mathrm{O}$ production and their ratio (e.g. Swerts et al., 1995; Wang et al., 2011; Kulkarni et al., 2014). It is important to note that these new methods are based on extracted soil cores, incubated over extended periods, which can create artificial conditions (Frank and Groffman, 2009). However, some confidence in the flux estimates from cores can be developed by comparing estimates of $\mathrm{CO}_{2}$ and $\mathrm{N}_{2} \mathrm{O}$ fluxes in the cores and in situ field chambers.

The new soil core incubation systems, along with new soil $\mathrm{O}_{2}$ sensors, have also advanced our understanding of hot moments of denitrification. Because it is possible to vary the $\mathrm{O}_{2}$ concentration of the recirculation stream in the new incubation systems, denitrification- $\mathrm{O}_{2}$ relationships can be established and linked with continuous estimates of soil $\mathrm{O}_{2}$ from the new sensors to produce continuous estimates of flux (Burgin and Groffman, 2012; Duncan et al., 2013). Recent studies have shown that these relationships are more complex than previously thought. For example, in northern hardwood forests in north-eastern North America, denitrification rates have been found to be higher at 5 or $10 \% \mathrm{O}_{2}$ than under completely anaerobic conditions, suggesting that there is tight coupling between $\mathrm{NO}_{3}^{-}$production by nitrification and denitrification in these soils (Morse et al., 2015).

As our ability to quantify denitrification has improved, our understanding of the factors that control the occurrence of hotspots and hot moments of activity has also increased. Riparian zones have been studied in this regard for several decades (e.g. Lowrance et al., 1997; Mayer et al., 2007). This has resulted in efforts to protect and restore riparian zones to decrease $\mathrm{N}$ delivery to receiving waters in many locations. Still, there is great uncertainty about just how much $\mathrm{N}$ is denitrified in riparian zones and through other $\mathrm{N}$ control practices, and how much $\mathrm{N}$ remains in the soils and vegetation of these areas where it is susceptible to later conversion back into $\mathrm{NO}_{3}^{-}$or $\mathrm{N}_{2} \mathrm{O}$ (Woli et al., 2010).

There has long been recognition of the potential for hotspot and hot moment denitrification to occur within crop fields or pastures. Periods of transient saturation low in the soil profile can support significant amounts of denitrification that are missed in sampling programs that focus on surface soils (Werner et al., 2011; Morse et al., 2014). Areas of wet soil, low soil $\mathrm{O}_{2}$, and possibly high denitrification are also common at the transition between fall and winter and between winter and spring (Walter et al., 2000). Animal grazing and excretion can create hotspots of $\mathrm{N}$ deposition, mineral- 
ization, nitrification, denitrification, and $\mathrm{N}_{2} \mathrm{O}$ flux (de Klein et al., 2014).

Experiments incorporating new ideas about hotspots and hot moments can benefit from recent studies that have characterized diversity in denitrifying phenotypes that reflect adaptation to prevailing environmental conditions with consequences for denitrification activity (Bergaust et al., 2011). These ideas have the potential to improve these experiments by allowing for more mechanistic, hypothesis-driven approaches that underlie more "black-box" ideas based on proximal drivers of denitrification.

Estimates of denitrification produced by direct measurement in soil cores can be validated using isotope measurements and models. Shifts in ${ }^{15} \mathrm{~N}_{-} \mathrm{NO}_{3}^{-}$have been used to indicate denitrification in soils, riparian zones, agricultural streams, and large rivers (e.g. Kellman and Hillaire-Marcel, 1998; Vidon and Hill, 2004). Dual natural isotope $\left(\delta^{18} \mathrm{O}\right.$ and $\delta^{15} \mathrm{NO}_{3}^{-}$) analysis has been used to estimate denitrification in aquifers (Wassenaar, 1995), agricultural (Burns et al., 2009) and urban (Kaushal et al., 2011) catchments, and in tropical forest soils (Houlton et al., 2006).

The time is thus ripe for ecosystem-, landscape-, and regional-scale studies of denitrification. We have new methods capable of producing well-constrained estimates of denitrification at the ecosystem scale and new ideas about the occurrence of hotspots and hot moments at ecosystem and landscape scales. In combination with independent approaches for validation of denitrification estimates, our estimates of this important process are likely to improve markedly over the next decade.

\section{$3{ }^{15} \mathrm{~N}$ tracing modelling for understanding $\mathrm{N}$ cycling processes}

This section will focus on how ${ }^{15} \mathrm{~N}$ enrichment in combination with process oriented modelling (Rütting et al., 2011b; Huygens et al., 2013) has helped to advance our understanding of $\mathrm{N}$ cycling dynamics in soils, and will be able to do so further in the future.

The stable isotope ${ }^{15} \mathrm{~N}$ has been used as a tracer for the quantification of gross $\mathrm{N}$ transformation rates for 60 years. In their two seminal papers, Kirkham and Bartholomew (1954, 1955) developed the isotope pool dilution technique, enabling for the first time the quantification of gross transformation rates of $\mathrm{N}$ cycling processes. Quantification of gross rates has deepened our understanding of the terrestrial N cycle tremendously. For example, Davidson et al. (1992) showed that old-growth forests exhibit high gross mineralization rates, challenging the paradigm (based on net mineralization rate measurements) that these ecosystems have low mineralization activity. The isotope pool dilution technique is still widely used, even though it has some important limitations. The most crucial disadvantage is that only total production and consumption rates of a labelled $\mathrm{N}$ pool can be quantified, which may be the result of several simultaneously occurring N processes (Schimel, 1996). For example, gross nitrification as quantified by the isotope pool dilution technique can be comprised of two separate processes, autotrophic $\left(\mathrm{NH}_{4}^{+}\right.$oxidation) and heterotrophic (the oxidation of organic $\mathrm{N}$ to $\mathrm{NO}_{3}^{-}$) nitrification. To overcome this limitation, ${ }^{15} \mathrm{~N}$ labelling can be done in conjunction with numerical ${ }^{15} \mathrm{~N}$ tracing models (Rütting et al., 2011b). These models describe the flow of $\mathrm{N}$ and ${ }^{15} \mathrm{~N}$ though the various soil $\mathrm{N}$ pools (e.g. $\mathrm{NH}_{4}^{+}, \mathrm{NO}_{3}^{-}$and organic $\mathrm{N}$ ), whereby transformations are represented by kinetic equations (e.g. zero- or first-order kinetics). The first ${ }^{15} \mathrm{~N}$ tracing model which could separate autotrophic from heterotrophic nitrification was presented by Myrold and Tiedje (1986). Subsequent studies using ${ }^{15} \mathrm{~N}$ tracing models have shown that heterotrophic nitrification can be a significant or even the dominant $\mathrm{NO}_{3}^{-}$production pathway in forest and grassland soils (Barraclough and Puri, 1995; Rütting et al., 2008; Taylor et al., 2013). In addition, ${ }^{15} \mathrm{~N}$ tracing models have been shown to be useful for investigating the importance of DNRA in various soils (Rütting et al., 2011a). Moreover, they can be used to distinguish DNRA from alternative pathways such as remineralization and plant efflux (Burger and Jackson, 2004). Recently, an ${ }^{15} \mathrm{~N}$ amino acid pool dilution approach has been developed (Wanek et al., 2010), which can be a useful tool for investigating whether depolymerization or $\mathrm{N}$ mineralization is the rate limiting step of the terrestrial $\mathrm{N}$ cycle (Schimel and Bennett, 2004), particularly if incorporated in numerical ${ }^{15} \mathrm{~N}$ tracing models.

In addition to quantification of gross $\mathrm{N}$ transformation rates, ${ }^{15} \mathrm{~N}$ enrichment has proven useful for partitioning nitrous oxide $\left(\mathrm{N}_{2} \mathrm{O}\right)$ emission sources. Using a two-source mixing model, Stevens et al. (1997) investigated the contribution of $\mathrm{NO}_{3}^{-}$reduction (i.e. denitrification) and $\mathrm{NH}_{4}^{+}$oxidation (i.e. autotrophic nitrification) to $\mathrm{N}_{2} \mathrm{O}$ emission. Subsequent work, however, suggested that organic $\mathrm{N}$ can be a third substrate for $\mathrm{N}_{2} \mathrm{O}$ production. Indeed, ${ }^{15} \mathrm{~N}$ studies using a triplet tracer approach and either analytical (Stange et al., 2009) or numerical (Stange et al., 2013; Müller et al., 2014) ${ }^{15} \mathrm{~N}$ tracing models showed a significant or even dominant contribution of oxidation of organic $\mathrm{N}$ (heterotrophic nitrification) to $\mathrm{N}_{2} \mathrm{O}$ production in soils. The numerical models have the additional advantage that gross $\mathrm{N}_{2} \mathrm{O}$ production rates can be quantified. Using oxygen isotopes $\left({ }^{18} \mathrm{O}\right)$ as an additional tracer allows the separation of $\mathrm{NH}_{4}^{+}$-derived $\mathrm{N}_{2} \mathrm{O}$ emission between $\mathrm{NH}_{4}^{+}$oxidation and nitrifier-denitrification (Kool et al., 2011a). The limitations and opportunities of this approach are discussed in Sect. 2.1. A further step for understanding sources of $\mathrm{N}_{2} \mathrm{O}$ emission from soil would be to incorporate ${ }^{18} \mathrm{O}$ into numerical tracing models, i.e. development of a combined ${ }^{15} \mathrm{~N}$ and ${ }^{18} \mathrm{O}$ tracer model. Overall, stable isotope labelling approaches $\left({ }^{15} \mathrm{~N}\right.$ and $\left.{ }^{18} \mathrm{O}\right)$ have greatly increased our understanding of the diverse $\mathrm{N}$ cycle processes contributing to $\mathrm{N}_{2} \mathrm{O}$ production in soils. Moreover, 
a
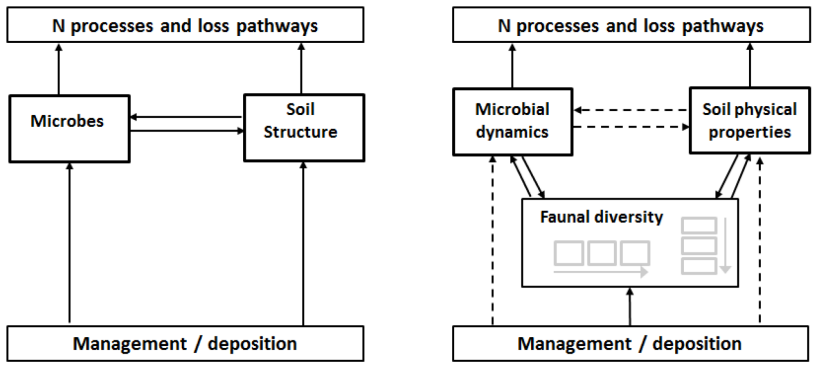

Figure 4. The influence of soil fauna on soil $\mathrm{N}$ processes and loss pathways. Conventionally (a), these processes and loss pathways were often considered as the result of interactions between microbes and soil structure. More recently (b), it is recognized that many microbial and physical properties are influenced by faunal diversity through trophic relationships and through changes in the soil structure by ecosystem engineers.

these studies have confirmed the importance of $\mathrm{NO}_{2}^{-}$dynamics for $\mathrm{N}_{2} \mathrm{O}$ production (Stange et al., 2013; Müller et al., 2014) and for the soil N cycle in general (Rütting and Müller, 2008; Isobe et al., 2012).

\section{Ecological interactions and $\mathrm{N}$ cycling processes}

\subsection{Soil fauna}

Until recently, the influence of soil fauna on the soil $\mathrm{N}$ cycle in agroecosystems has been mostly neglected. Nitrogen transformation processes and nitrogen loss pathways have almost exclusively been related to the interplay between microbial dynamics in the soil and abiotic factors. At first glance this seems logical: microorganisms dominate the biomass of soil life to a large degree, and many conversions in the $\mathrm{N}$ cycle (e.g. nitrification, denitrification, nitrifier-denitrification, $\mathrm{N}$ fixation, DNRA) are the exclusive domain of microorganisms. Biochemical and physical processes, such as nitrification and $\mathrm{N}$ leaching are controlled by abiotic factors (e.g. $\mathrm{pH}$, porosity and temperature). In turn, both microbial dynamics and abiotic factors can be changed by human influences such as $\mathrm{N}$ deposition in natural systems and fertilization, liming, soil tillage, and animal husbandry in agricultural systems (Fig. 4a).

What important role do soil fauna then have in the $\mathrm{N}$ cycle? Like the effect of humans, their role can be dramatic but is essentially indirect: through trophic interactions and burrowing activities they may strongly affect microbial dynamics in the soil and soil physical properties (Fig. 4b).

The only part of the soil $\mathrm{N}$ cycle where the role of soil fauna has been reasonably well established is $\mathrm{N}$ mineralization and subsequent plant uptake. Soil fauna affects $\mathrm{N}$ mineralization by a combination of activities, including trophic interactions (grazing on microorganisms, predation), fragmentation of organic matter, mixing organic matter into the soil, excreting nutrient-rich compounds, and dispersing microbial propagules (Bardgett and Chan, 1999).

In a literature study across natural and agricultural systems, Verhoef and Brussaard (1990) found a relatively stable faunal contribution to $\mathrm{N}$ mineralization of around $30 \%$. Different functional groups of soil fauna, however, contribute to $\mathrm{N}$ mineralization differently, with the largest contributions provided by bacterial-feeding microfauna (nematodes and amoeba), followed by earthworms and potworms, and minor contributions by fungal-feeding nematodes and microarthropods (De Ruiter et al., 1993). Among meso- and macrofauna, the role of earthworms has been most extensively studied (e.g. Postma-Blaauw et al., 2006; Van Groenigen et al., 2014). As "ecosystem engineers", they are well known to affect soil structure and litter redistribution, thereby affecting many aspects of the $\mathrm{N}$ cycle and other soil processes (Shipitalo and Le Bayon, 2004; Blouin et al., 2013). In a recent meta-analysis, Van Groenigen et al. (2014) showed that in agricultural systems earthworms increase crop yield on average by $25 \%$. This effect was consistent between different functional groups of earthworms, but increased with earthworm density and crop residue application rates. Because this beneficial effect disappeared with adequate $\mathrm{N}$ fertilization, it was mainly ascribed to increased $\mathrm{N}$ mineralization from crop residue and soil organic matter. In tropical ecosystems, soil-feeding termites are known to have a similarly large impact on $\mathrm{N}$ mineralization (Ji and Brune, 2006). Termites are also able to volatilize ammonia from their gut and faeces. However, this has only been shown to lead to high $\mathrm{NH}_{3}$ concentrations in their nest atmosphere. It is not yet clear whether the $\mathrm{NH}_{3}$ accumulating in the internal nest atmosphere can escape into the ambient air ( $\mathrm{Ji}$ and Brune, 2006).

The effect of faunal diversity rather than single faunal groups is complex. Combinations of functionally dissimilar soil fauna can increase the $\mathrm{N}$ mineralization rate due to facilitative interactions (Heemsbergen et al., 2004). These include one group benefitting from the activity of another group, for example through changes in soil structure or litter shredding by isopods promoting microbial growth (Wardle, 2006). However, competitive interactions may also positively influence mineralization rates (Loreau, 1998). For instance, predatory mites in the soil feed on fungivorous mites and potworms, springtails, and nematodes (De Ruiter et al., 1995), and can thereby influence microbial activities through trophic cascades (induced positive effects on microbes by feeding on microbial feeders). Even though empirical evidence of such trophic cascades in soil food webs is scarce (Mikola and Setälä, 1998; Bardgett and Wardle, 2010), the presence of predatory mites can potentially influence the behaviour of fungivorous mites and potworms in terms of their feeding rate and spatial distribution. Such interactions (both facilitative and competitive), within and across trophic levels, have not yet been explored for most $\mathrm{N}$ cycling processes, including $\mathrm{N}$ loss pathways. 
Among the relatively few studies that have focused on processes other than $\mathrm{N}$ mineralization, earthworms are again by far the most studied group. They have been shown to affect microbial N immobilization (Brown et al., 1998) as well as nitrification and denitrification (e.g. Parkin and Berry, 1999; Rizhiya et al., 2007). A growing body of literature shows that earthworms can considerably increase $\mathrm{N}_{2} \mathrm{O}$ emissions (Lubbers et al., 2013). A recent meta-analysis on the effect of earthworms on soil greenhouse gas emissions reported an average earthworm-induced increase in $\mathrm{N}_{2} \mathrm{O}$ emissions of $42 \%$ (Lubbers et al., 2013). This was hypothesized to be the result of effects on the denitrifier community as well as changes in soil structure affecting gas diffusivity and anaerobicity (Drake and Horn, 2006, 2007; Nebert et al., 2011). Further work on soil microbiology and soil structure is needed to determine what are the exact effects of earthworm activity on microbial producers and consumers of $\mathrm{N}_{2} \mathrm{O}$ and on net soil $\mathrm{N}_{2} \mathrm{O}$ emission. Molecular microbial analysis and soil X-ray tomography are state-of-the-art experimental techniques that may shed more light on the mechanisms behind earthworm effects on $\mathrm{N}_{2} \mathrm{O}$ emission.

Evidence for involvement of other faunal groups in these processes is scarce. Potworms, phylogenetically related to earthworms and with similar foraging and burrowing habits (albeit at a smaller scale), have been recognized as vectors for microbial colonization (Rantalainen et al., 2004) and may influence both nitrification and denitrification processes (Van Vliet et al., 2004). High soil $\mathrm{NO}_{3}$ levels in the presence of potworms have been linked to increased nitrification potential (Liiri et al., 2007). Recent work has shown that trophic interactions involving fungivorous and predatory mites and springtails can strongly affect $\mathrm{N}_{2} \mathrm{O}$ emissions (Kuiper et al., 2013; Thakur et al., 2014), although the exact pathways remain unclear - both "real" trophic relations as well as altered behaviour due to sensing of the presence of predators may play a role.

Changes in soil structure (porosity, aggregation) by faunal activity can affect soil physical processes as well. Burrowing activities of earthworms may create preferential flow pathways that increase leachate volume and consequently the total leaching loss of inorganic $\mathrm{N}$ and dissolved organic $\mathrm{N}$ (e.g. Dominguez et al., 2004). Interactions between other soil faunal species have received little attention with regard to their effects on soil physical properties. Smaller fauna such as potworms, springtails, mites, and nematodes are often assumed to have negligible direct effects on larger-scale soil structure, because they are usually confined to pre-existing voids in litter or soil (Lee and Foster, 1991; Whalen and Sampedro, 2010). However, these small fauna can significantly alter soil microstructure by producing faecal pellets, and potworms can also increase soil porosity and pore continuity by their burrowing activity (Topoliantz et al., 2000; Van Vliet et al., 2004).

Overall, soil biota are essential for maintaining healthy soils and providing ecosystem services, such as $\mathrm{N}$ mineral- ization and plant uptake for food, fuel, and fiber production. However, it is not clear whether they are able to do so without creating detrimental effects on $\mathrm{N}$ loss pathways such as $\mathrm{N}$ leaching and $\mathrm{N}_{2} \mathrm{O}$ emissions. Understanding the role of soil fauna in soil $\mathrm{N}$ research should therefore focus on potential trade-offs between the need to produce enough food, fuel, and fiber on the one hand, and the need to mitigate global warming and avoid biodiversity loss due to eutrophication on the other. So far, mechanistic knowledge on the controlling factors for possible mitigation options is largely lacking. Addressing the question of how to reap the benefits of a diverse soil community while avoiding the drawbacks will provide fundamental insights that can be used to design future sustainable agricultural systems.

\subsection{Rhizodeposition and plant traits}

Soil microbial communities depend almost exclusively on plant-derived resources for their energy and nutrient supply. For a long time, it was presumed that plant litter was the most relevant organic matter input for the soil food web and that plant effects on soil biogeochemistry were mainly mediated via the indirect impacts of plant inputs on relatively inert soil properties. Therefore, most of our initial understanding of soil biogeochemistry was based on experiments with rootfree soils.

The impact of spatially and temporarily dynamic processes occurring in the rhizosphere on $\mathrm{N}$ cycling has rarely been considered (Frank and Groffman, 2009; Rütting et al., 2011b). Nevertheless, an important share of the energy for microbial metabolism is delivered by belowground plant parts through root exudation, cell sloughing, and root and mycorrhizal fungal turnover (Nguyen, 2003). Healthy growing roots pass a large proportion of the $\mathrm{C}$ they receive to the soil as root exudates. This includes a range of materials, but soluble compounds, consisting of organic acids, carbohydrates, and amino acids, comprise the largest component (Farrar et al., 2003). The total amount and composition of root exudates varies between plant species and genotypes, and is influenced by plant phenology and environmental conditions (Nguyen, 2003). Moreover, fine root turnover, caused by the production, mortality, and decay of short-lived C-rich roots, is another key pathway of significant nutrient flux in terrestrial ecosystems that may equal or even exceed that of aboveground litter fall in certain ecosystems (Gill and Jackson, 2000; Yuan and Chen, 2010).

There are several mechanisms through which plant roots can affect rhizosphere N cycling (reviewed in Paterson, 2003; Dijkstra et al., 2013; Cheng et al., 2014). Rhizodeposition may enhance microbial growth and activity and stimulates production of microbial exoenzymes that "mine" for more complex soil organic $\mathrm{N}$ compounds, a process often referred to as "priming" (Paterson, 2003). Nitrogen immobilized by the microbial community may temporarily reduce soil $\mathrm{N}$ availability, but immobilized $\mathrm{N}$ can become available in the 
rhizosphere due to microbial turnover and the grazing of rhizosphere microorganisms by soil microfauna (see Sect. 4.1). The quality of rhizodeposition is an important determinant for soil microbial communities; any shifts in their composition may affect decomposition processes through the production of distinct sets of extracellular enzymes (Dennis et al., 2010; Kaiser et al., 2010). Nevertheless, under conditions of low $\mathrm{N}$ availability, plant $\mathrm{N}$ uptake may limit microbial substrate $\mathrm{N}$ availability and reduce microbial growth and decomposition activity (Dijkstra et al., 2010; Blagodatskaya et al., 2014). Moreover, the production of specific metabolites that act as signaling molecules could accelerate or retard soil $\mathrm{N}$ cycling if they act upon certain functional microbial taxa (De-la-Pena and Vivanco, 2010). Finally, specific $\mathrm{N}$ cycling processes, such as denitrification or $\mathrm{N}$ fixation, could be altered in the rhizosphere due to altered microbial substrate conditions, encompassing $\mathrm{C}, \mathrm{O}_{2}$, and $\mathrm{NO}_{3}^{-}$availabilities (Philippot et al., 2009). Altogether, rhizodeposition mostly causes an increase in microbial activity and soil $\mathrm{N}$ decomposition compared to bulk soils. Nevertheless, nutrient availability in the rhizosphere and competitive interactions between plant and microbial communities may shift the magnitude and direction of $\mathrm{N}$ cycling processes. This holds especially true for those processes that are performed by phylogenetically less diverse microbial functional groups; processes such as nitrification and methane uptake should therefore be much more sensitive to shifts than $\mathrm{N}$ mineralization (Philippot et al., 2009; Dijkstra et al., 2013).

Although the quality and quantity of rhizodeposits clearly influence rhizosphere $\mathrm{N}$ cycling, a major challenge lies in determining to what extent plant community characteristics explain the observed variations of rhizosphere impacts (Cheng et al., 2014). Considering the great difficulties in assessing rhizodeposition under field conditions (Pausch et al., 2013a), a prospective approach may involve measuring "soft" plant traits that are relatively easy to observe and quantify (Fry et al., 2014). There are several traits that are good candidates due to their putative intimate relationship with rhizodeposition. For example, root exudation is linked to the intensity of canopy photosynthetic activity and photo-assimilate supply (Kuzyakov and Cheng, 2001). Fast-growing, acquisitive plants with high specific leaf area and short lifespan are thus thought to be associated with a larger rhizosphere effect (Wardle et al., 2004). Because root exudation is concentrated at the apices of the roots and at the nodes where lateral roots emerge (Jaeger et al., 1999), root architectural traits determine the expansion of the rhizosphere and exudate fluxes per unit of root biomass. A densely branched root system with high biomass and a rapid turnover thus contributes large quantities of exudates (Van der Krift et al., 2001). The chemistry of rhizodeposits is a key controlling variable of rhizosphere dynamics, as microbial communities may shift their $\mathrm{N}$ use efficiency in response to substrate stoichiometry, leading to changes in soil $\mathrm{N}$ cycling fluxes (Moorshammer et al., 2014).
Several studies have examined presumed relationships between $\mathrm{N}$ cycling parameters and plant traits, especially of aboveground plant organs (e.g. Wedin and Tilman, 1990; Orwin et al., 2010; Garcia-Palacios et al., 2013; Grigulis et al., 2013). Soil $\mathrm{N}$ cycling processes appear to be primarily driven by traits of the most abundant species (the biomass ratio hypotheses; Grime, 1998), although complex effects may arise due to interspecies interactions and non-additive species effects (Grigulis et al., 2013; Pausch et al., 2013b). These studies confirm that plant characteristics, including underinvestigated root traits, exert a key control over soil microbial communities and modify the fundamental physiologies that drive soil $\mathrm{N}$ cycling. Nevertheless, the lack of clear-cut relationships between specific plant traits and $\mathrm{N}$ cycling parameters indicates the necessity for more research on plant communities to establish consistent links between plant traits and $\mathrm{N}$ cycling variables, especially under field conditions.

\subsection{Mycorrhizal associations}

This section will focus on the extent to which the main types of mycorrhizal symbioses, arbuscular mycorrhiza and ectomycorrhiza, differentially affect the soil N cycle. Early conceptual models linked the replacement of arbuscular mycorrhizal plants by ectomycorrhizal plants to succession (Read, 1991) or to latitudinal and altitudinal gradients from warmer to colder climates (Read and Perez-Moreno, 2003). This was considered to be driven by shifts from $\mathrm{P}$ to $\mathrm{N}$ limitation, where simultaneously an increasing fraction of the $\mathrm{N}$ and $\mathrm{P}$ was present in organic forms to which ectomycorrhizal fungi were supposed to have better access than arbuscular mycorrhizal fungi. However, Dickie et al. (2013) noted a poor fit between these models and actual data on primary succession and suggested that nutrient limitation shifts from $\mathrm{N}$ to $\mathrm{P}$ limitation in retrogressive succession. Although a new model of general applicability has not yet been proposed, the underlying idea of a fundamental difference between arbuscular mycorrhiza-dominated ecosystems, with more open, inorganic nutrient cycles, and ectomycorrhiza-dominated ecosystems, with more closed, organic nutrient cycles has persisted, especially for forests in temperate regions (Phillips et al., 2013; Bradford, 2014). We note that the same distinction was proposed between bacterial- and fungal-dominated agroecosystems by De Vries and Bardgett (2012). Their conceptual model is apparently not applicable for the tropics, where both arbuscular mycorrhizal and ectomycorrhizal forests are characterized by an open N cycle (Kuyper, 2012; Tedersoo et al., 2012). This geographical contrast raises the question of to what extent the nature of the mycorrhizal symbiosis is causally relevant for differences in forest ecosystem functioning, or if plant traits other than the mycorrhizal symbiosis cause these differences. Arguments that the mycorrhizal symbiosis is causally relevant for soil $\mathrm{N}$ cycling are connected to the claim that ectomycorrhizal fungi, contrary to arbuscular mycorrhizal fungi, possess extensive saprotrophic 
activity and are therefore able to make $\mathrm{N}$ available in the soil ("mining") (Koide et al., 2008; Talbot et al., 2008), and therefore could access organic sources of $\mathrm{N}$ and phosphorus.

Several authors have compared uptake of various amino acids by arbuscular and ectomycorrhizal plants. The ability to depolymerize large $\mathrm{N}$-containing molecules (proteins) into smaller fragments that can be taken up (Schimel and Bennett, 2004) and the ability to increase access to these large molecules, which are often bound to phenolics and other recalcitrant compounds, have been mainly studied for ectomycorrhizal fungi. Talbot and Treseder (2010) demonstrated the widespread ability among ectomycorrhizal fungi to take up amino acids and noted that the relative benefit of the symbiosis was largest for the most common amino acids. Arbuscular mycorrhizal fungi also have widespread ability to take up amino acids (Whiteside et al., 2012). Arbuscular mycorrhizal plants took up significantly larger amounts of eight amino acids (phenylalanine, lysine, asparagine, arginine, histidine, methionine, tryptophan, and cysteine) than non-mycorrhizal plants and significantly smaller amounts in the case of aspartic acid. Contrary to the hypothesis of Talbot and Treseder (2010) for ectomycorrhizal plants, the authors noted that the mycorrhizal effect on uptake was inversely related to the abundance of that amino acid in the database of all known proteins. The authors speculated that preferential use of rare amino acids by arbuscular mycorrhizal plants may reduce competition with ectomycorrhizal plants for amino acids. However, the extent to which this form of niche differentiation would reduce competition depends on the rate at which amino acids become available in the soil solution and hence to what extent the two preceding steps (increased access to protein-polyphenol complexes; depolymerization of proteins) are rate-limiting. It is therefore necessary to assess the mycorrhizal role in those two steps.

Lindahl et al. (2007) showed an increased $\mathrm{C}: \mathrm{N}$ ratio in deeper humus layers, and this effect was attributed to selective $\mathrm{N}$ mining by ectomycorrhizal fungi. Several studies have provided explicit support that ectomycorrhizal fungi can mine humus layers for $\mathrm{N}$ and have identified the relevant ectomycorrhizal fungi (Hobbie et al., 2013; Rineau et al., 2013; Bödeker et al., 2014). Wu (2011) on the other hand claimed that direct access by ectomycorrhizal fungi to $\mathrm{N}$ from the protein-polyphenol complex is likely limited and attributed a major role for interactions between saprotrophic and ectomycorrhizal fungi. Current evidence suggests that arbuscular mycorrhizal fungi have neither the ability to degrade humus for N-rich compounds nor the ability to depolymerize proteins into amino acids. The widespread ability of arbuscular mycorrhizal fungi to take up amino acids may therefore not be related to closed nutrient cycles with a major role for uptake of organic nutrients, but may rather function as a scavenging mechanism to re-absorb exudates, including amino acids. More information about the role of arbuscular mycorrhiza in the uptake of organic $\mathrm{N}$ is provided in recent reviews by Veresoglou et al. (2012) and Hodge and Storer (2015)

The stable isotope ${ }^{15} \mathrm{~N}$ has been used to study the role of mycorrhizal symbioses in accessing different $\mathrm{N}$ pools. Whereas early studies had examined the congruence between the ${ }^{15} \mathrm{~N}$ signal of a potential $\mathrm{N}$ source and that of mycorrhizal fungi as evidence for uptake from that source, recent studies have emphasized the importance of $\mathrm{N}$ partitioning between fungus and plant (fractionation of $\mathrm{N}$-depleted chitin or enriched proteins that are transferred to the plant) as a major control of isotopic composition (Hobbie and Högberg, 2012). Both the ability to take up $\mathrm{N}$ from organic sources (proteolytic fungi) and a relatively large transfer from fungus to plant are consistent with ${ }^{15} \mathrm{~N}$ enrichment of ectomycorrhizal fungi. Both mechanisms are likely correlated as fungi in more $\mathrm{N}$-limited sites transfer relatively more $\mathrm{N}$ per unit of $\mathrm{C}$ at the symbiotic interface. Further study of both traits is needed to better understand ectomycorrhizal fungal isotopic signatures, and especially cases of extreme enrichment (up to $20 \%$ ) where the nature of the $\mathrm{N}$ source is unknown.

A corollary of the conceptual model of Phillips et al. (2013) and of earlier models is that arbuscular mycorrhizal and ectomycorrhizal plants differ in their carbon and nutrient cycling traits (decomposability and nutrient release). Data by Cornelissen et al. (2001) were consistent with this prediction, showing that the mycorrhizal trait is a predictor for the so-called "fast-slow" spectrum (Reich, 2014). However, the comparison involved plant species that are not only different with regard to the mycorrhizal trait but also with regard to a number of other traits. Koele et al. (2012) applied phylogenetic correction, by comparing sister clades that differed only in their mycorrhizal habit. Their data, based on 17 pairs of taxa, indicate no differences in leaf $\mathrm{N}$ or phosphorus status after phylogenetic correction and imply that the mycorrhizal trait is correlated rather than causally related with these functional differences. Other claims about differences in $\mathrm{N}$ cycling between arbuscular mycorrhizal and ectomycorrhizal forests in the northern temperate zone may similarly indicate problems of establishing whether mycorrhizal status is a causally relevant or only a correlated trait. Thomas et al. (2010) showed a larger positive response to $\mathrm{N}$ deposition by arbuscular mycorrhizal than ectomycorrhizal trees, suggesting that the ability of the latter group to acquire organic $\mathrm{N}$ was traded off against the possibility of benefitting from increased inorganic N. Midgley and Phillips (2014) reported higher $\mathrm{NO}_{3}^{-}$leaching in arbuscular mycorrhizal forests than in ectomycorrhizal forests, but as most of the data on arbuscular mycorrhizal forests pertain to maple (Acer saccharum) forests, the generality of that pattern needs further study.

Averill et al. (2014) reported that competition between ectomycorrhizal fungi/plants and decomposer microbiota results in $\mathrm{N}$ limitation for the latter group, which retards litter breakdown and hence results in increased $\mathrm{C}$ storage. They noted $70 \%$ more $\mathrm{C}$ storage per unit $\mathrm{N}$ in ectomycorrhizal 
forests than in forests dominated by arbuscular mycorrhizal trees and suggested that mycorrhizal status exerts a much larger control over soil $\mathrm{C}$ than climatic variables at the global scale. However, this effect appears to be mainly driven by boreal trees (there is a dominance in the database of ectomycorrhizal trees belonging to the Pinales and Fagales, both orders that are characteristic of nutrient-poor soils), and the effect is only marginally significant when the analysis is performed on temperate and tropical forests (Averill et al., 2014). Therefore, plant traits that are inherently associated to mycorrhizal status should further be considered when assessing the key drivers of the differential $\mathrm{C}: \mathrm{N}$ stoichiometry and $\mathrm{C}$ storage.

Nitrogen immobilization in the mycorrhizal mycelium may also have a large impact on the $\mathrm{N}$ cycle by reducing mineral $\mathrm{N}$ availability for plants. The general claim that mycorrhizal symbioses are beneficial for the plant and that cases of a negative plant performance in the mycorrhizal condition are explained by $\mathrm{C}$ costs of the symbiosis was refuted by Côrrea et al. (2012), who concluded that smaller plant size was caused by lower $\mathrm{N}$ uptake. Lower $\mathrm{N}$ content of the ectomycorrhizal plant could be due to mycorrhiza-driven progressive N limitation (Luo et al., 2004). Alberton et al. (2007) showed this to be the case as plant $\mathrm{N}$ content was significantly negatively correlated with hyphal length. Näsholm et al. (2013) showed that immobilization of $\mathrm{N}$ in the ectomycorrhizal mycelium can aggravate plant $\mathrm{N}$ limitation. They modelled competition between plants and fungi for $\mathrm{N}$ in a market model, and concluded that at $\mathrm{N}$ limitation the symbiosis does not alleviate plant $\mathrm{N}$ limitation but in fact even reduces plant growth (Franklin et al., 2014; Kuyper and Kiers, 2014). Yet, despite this negative effect on plant performance, a nonmycorrhizal strategy is competitively inferior, and therefore trees are trapped as they cannot terminate the association. Because the biomass of the arbuscular mycelium is usually one or two orders of magnitude smaller than that of the ectomycorrhizal mycelium, the amount of $\mathrm{N}$ immobilized by the arbuscular mycorrhizal mycelium is sometimes hypothesized to be quantitatively unimportant from the plant's perspective. However, recent studies (Hodge and Fitter, 2010; Grman and Robinson, 2013) indicate that $\mathrm{N}$ uptake and immobilization by arbuscular mycorrhizal fungi can also reduce plant performance.

Other pathways through which the mycorrhizal symbiosis may affect soil $\mathrm{N}$ cycling are modification of root exudation, root architecture, and fine root turnover (Churchland and Grayston, 2014). It is important to determine which of these differences are caused by the symbiosis and which by other root trait differences among species. For example, Comas et al. (2014) found that, after accounting for phylogenetic relationships, ectomycorrhizal plants have thinner roots and greater branching intensity than arbuscular mycorrhizal plants. It is therefore still a matter of debate whether differences with respect to the mycorrhiza-associated nutrient economy (Phillips et al., 2013) are controlled by the mycor- rhizal trait, or whether the mycorrhizal trait is instead correlated with causally relevant plant and climate traits.

\section{$4.4 \mathrm{~N}_{2}$ fixation}

An important share of bioavailable $\mathrm{N}$ enters the biosphere via biological fixation of atmospheric $\mathrm{N}_{2}$ (BNF) (Vitousek et al., 2013). Biological $\mathrm{N}$ fixation can be natural (e.g. $\mathrm{N}_{2}$ fixing trees that are present in forest ecosystems) or anthropogenic (e.g. $\mathrm{N}_{2}$ fixation by leguminous agricultural crops). Two types of BNF, both using the nitrogenase enzyme, are present in nature: symbiotic $\mathrm{N}_{2}$ fixation $(\mathrm{S}-\mathrm{BNF})$ and freeliving $\mathrm{N}_{2}$ fixation (F-BNF). Symbiotic $\mathrm{N}_{2}$ fixation is here defined via the infection of plant roots by bacteria - such as Rhizobia, Bradyrhizobia, or actinomycetes - followed by the formation of nodules. All other forms of BNF are regarded as free-living $\mathrm{N}_{2}$ fixation (including e.g. fixation by bacteria in soil and litter, but also $\mathrm{N}$ fixation in lichens) (Reed et al., 2011). Here we highlight the importance of $\mathrm{N}_{2}$ fixation for $\mathrm{N}$ budgets in pristine tropical forest, peatlands, and cryptogamic soil crusts, and for the sustainable production of biofuels.

Nitrogen demand in young successional tropical forest is high. The large fraction of leguminous plant species that forms symbiosis with $\mathrm{N}_{2}$-fixing bacteria has recently been identified as a key element of functional diversity for overcoming ecosystem-scale $\mathrm{N}$ deficiencies in tropical forest successions (Batterman et al., 2013a). Symbiotic fixation is thus considered to relieve $\mathrm{N}$ limitations and safeguard forest regrowth and $\mathrm{CO}_{2}$-accrual as an ecosystem service. Nevertheless, S-BNF has also been postulated as the reason why mature tropical forest, having a lower $\mathrm{N}$ demand than early succession stands, become relatively rich in $\mathrm{N}$ and as a consequence loses (sometimes large amounts of) bioavailable $\mathrm{N}$ (Hedin et al., 2009) via $\mathrm{NO}_{3}^{-}$leaching (e.g. Brookshire et al., 2012) or gaseous $\mathrm{N}$ loss (e.g. Werner et al., 2007).

However, a plant-level physiological perspective counters this assumption, as numerous experiments have shown that symbiotic S-BNF by leguminous species is mostly facultative and down-regulated when located in an N-rich environment. Tropical leguminous species thus have the potential to fix atmospheric $\mathrm{N}_{2}$, but it is likely that they only do so actively in young forest successions or disturbed ecosystems, and far less in mature forests. Secondly, only some individuals of the Fabaceae family have nodule-forming capacities (mainly belonging to the Mimosoideae and Papilionoideae subfamilies). This consideration decreases the omnipresence and abundance of potential $\mathrm{N}$ fixers in tropical forests, making their role as a vital chain in the tropical $\mathrm{N}$ cycle less credible. Therefore, Hedin et al. (2009) have suggested a possible mechanism for explaining this tropical $\mathrm{N}$ paradox via a "leaky nitrostat model" (Fig. 5). This concept brings forward the importance of F-BNF, which is hypothesized to take place, even in N-rich ecosystems, in localized N-poor microsites, such as litter layers, topsoil, canopy leaves, lichens, 


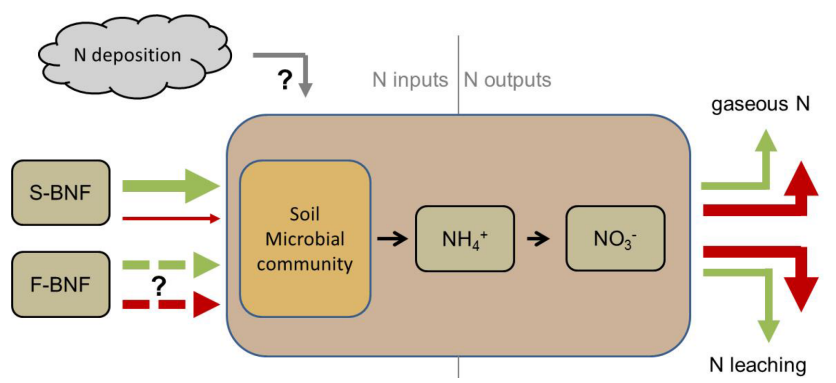

Figure 5. The leaky nitrostat model adapted from Hedin et al. (2009). This model indicates the importance of symbiotic (S$\mathrm{BNF}$ ) and free-living (F-BNF) biological $\mathrm{N}_{2}$ fixation along a forest successional gradient, from young (green) to mature (red) forest stands. At the initial stages of ecosystem succession, the $\mathrm{N}$ supply via S-BNF, F-BNF and N deposition supports high ecosystem $\mathrm{N}$ demands. In mature forest stands with a lower $\mathrm{N}$ demand, S-BNF is down-regulated, but $\mathrm{N}$ inputs via F-BNF and $\mathrm{N}$ deposition lead to ecosystem $\mathrm{N}$ losses via $\mathrm{N}$ leaching and gaseous $\mathrm{N}$ production.

or bryophytes on stems. Combined, these free-living $\mathrm{N}_{2}$ fixers would bring high amounts of $\mathrm{N}$ in the system, resulting in high $\mathrm{N}$ availability. However, spatially explicit data are virtually absent and largely based on geographically biased, indirect measurements using the acetylene reduction assay rather than direct ${ }^{15} \mathrm{~N}_{2}$ incubation measurements.

A recent spatial sampling method to assess total BNF indicated that tropical forest BNF is likely much lower than previously assumed (Sullivan et al., 2014). These authors reported mean rates of total BNF in primary tropical forests of $1.2 \mathrm{~kg} \mathrm{Nha}^{-1} \mathrm{yr}^{-1}$, while previous empirical or modelled data ranged between 11.7 and $31.9 \mathrm{~kg} \mathrm{Nha}^{-1} \mathrm{yr}^{-1}$. Secondary successional forests, as mentioned above, had higher total BNF than primary forest $\left(6.2-14.4 \mathrm{~kg} \mathrm{Nha}^{-1} \mathrm{yr}^{-1}\right)$. Sullivan et al. (2014) proposed a time-integrated total BNF rate of $5.7 \mathrm{~kg} \mathrm{~N} \mathrm{ha}^{-1} \mathrm{yr}^{-1}$ for primary forest in Costa Rica, of which $20-50 \%$ is attributed to S-BNF. It remains to be shown whether this BNF rate from primary tropical forest and proportions of S-BNF and F-BNF are valid for the pantropics. But if total BNF in tropical forests is indeed much lower than previously thought, this will fundamentally alter our assessment of tropical forest $\mathrm{N}$ cycles and the relative contribution of anthropogenic inputs (Sullivan et al., 2014). There is indeed emerging evidence that anthropogenic $\mathrm{N}$ deposition in tropical ecosystems is more substantial than assumed, as a result of biomass burning, dust and biogenic deposition (Chen et al., 2010; European Commission - Joint Research Centre, 2014; Cizungu et al., unpublished data). Hence, the relative contribution of human perturbation (e.g. wild fire, livestock, and fossil fuel combustion) to the tropical $\mathrm{N}$ cycle is likely much larger and warrants careful attention, e.g. by increasing $\mathrm{N}$ deposition measurement networks in tropical forests (Matson et al., 1999). Moreover, there is only limited understanding of the effects of proximate $(\mathrm{N}, \mathrm{P}$ and Mo availability) controls (Barron et al., 2009; Wurzburger et al., 2012; Batterman et al., 2013b), and the impact of global change factors (temperature, moisture, $\mathrm{N}$ deposition) on $\mathrm{F}$ BNF.

In boreal forests, symbiosis between cyanobacteria and feather mosses provides an important $\mathrm{N}$ input (DeLuca et al., 2002; Gundale et al., 2012). In peatlands, which contain approximately $30 \%$ of global soil carbon, Sphagnum mosses living in close association with methanotrophic bacteria, which can stimulate BNF and constitutes an important mechanism for $\mathrm{N}$ accumulation in peatlands (Larmola et al., 2014). These authors found $\mathrm{N}_{2}$ fixation rates between 1 and $29 \mathrm{~kg} \mathrm{Nha}^{-1} \mathrm{yr}^{-1}$, up to 10 times larger than current atmospheric $\mathrm{N}$ deposition rates. This also shows that $\mathrm{N}_{2}$ fixation contributes considerably to the $\mathrm{N}$ budget of peatlands. Cryptogamic covers that consist of cyanobacteria, algae, fungi, lichens, and bryophytes are suggested to account for approximately half ( $49 \mathrm{TgN}$ ) of the biological $\mathrm{N}_{2}$ fixation on land (Elbert et al., 2012). From a sustainable agronomic management point of view, associative $\mathrm{N}_{2}$ fixation could be promoted in certain crops. For example, field experiments with sugar cane and Miscanthus with little $\mathrm{N}$ input showed that a substantial portion of new plant $\mathrm{N}$ was derived from $\mathrm{N}_{2}$ fixation (Keymer and Kent, 2014).

While large uncertainties exist regarding the temporal and spatial variability, dominant determinants, and the magnitude and impact of BNF on terrestrial ecosystems functions and services, even less is known regarding its future trajectories in view of global change.

\section{Conclusions}

This is an exciting time to study the soil $\mathrm{N}$ cycle. Years of surprising findings on unanticipated pathways and mechanisms have expanded the horizons of researchers. These findings have stimulated efforts to develop and test new methods for quantifying these processes. This has resulted in a better understanding of the complexity of soil $\mathrm{N}$ cycling processes and in powerful tools for future exploration.

Critical challenges remain. Many processes are still difficult to quantify and variability and heterogeneity hamper our ability to provide well-constrained estimates relevant to water and air quality issues. We postulate that addressing the issues formulated above would constitute a comprehensive research agenda with respect to the $\mathrm{N}$ cycle for the next decade. Particularly, we urge the following blueprint for action:

1. abandoning the long-disproved but persistent assumption that gaseous $\mathrm{N}$ production in soils is the exclusive result of the interplay between nitrification and denitrification, and to focus on a better assessment of alternative pathways;

2. dedicating scientific efforts to the continuing development of improved techniques for the characterization, quantification, and modelling of alternative $\mathrm{N}$ transfor- 
mation pathways, eventually in conjunction with stateof-the-art molecular techniques to determine the functional microbial communities involved; and

3. considering ecological interactions and trophic cascades as indirect but essential drivers of soil $\mathrm{N}$ cycling, in particular in response to global change.

Success will require interactions between soil science and other disciplines that address both smaller (e.g. molecular and microbial) and larger (ecosystem, landscape, and regional) scales. We believe that such an agenda would help us meet future challenges of food and energy security, biodiversity conservation, and climate stability.

Author contributions. All authors contributed to selecting the topics addressed in this manuscript. P. Boeckx wrote the sections on BNF and $\mathrm{N}_{2} \mathrm{O}$ consumption; T. Rütting wrote the section on ${ }^{15} \mathrm{~N}$ models; D. Huygens and Th. W. Kuyper co-wrote the section on mycorrhizal associations; D. Huygens wrote the section on rhizodeposition and plant traits; I. M. Lubbers and J. W. van Groenigen cowrote the section on soil fauna; J. W. van Groenigen wrote the section on nitrifier denitrification; P. M. Groffman wrote the section on denitrification; J. W. van Groenigen, D. Huygens and P. M. Groffman co-wrote the remaining sections. All authors commented on the final draft.

Acknowledgements. The authors would like to thank the editors of SOIL for the invitation to write this review. J. W. van Groenigen and I. M. Lubbers were financially supported by an Netherlands Organization for Scientific Research (NWO; grant no. 823.01.016.). P. M. Groffman was partially supported by US National Science Foundation grant (grant no. NSF DEB 0919131). D. Huygens and P. Boeckx acknowledge the EU's Seventh Framework Program for Research (grant no. PIOF-GA-2011-301443) and the Fund for Scientific Research - Flanders (FWO). T. Rütting is financially supported by the Swedish strategic research area Biodiversity and Ecosystem services in a Changing Climate - BECC. Finally, we are thankful to three anonymous reviewers for their extensive and constructive comments on an earlier version of our paper.

Edited by: K. Kalbitz

\section{References}

Alberton, O., Kuyper, T. W., and Gorissen, A.: Competition for nitrogen between Pinus sylvestris and ectomycorrhizal fungi generates potential for negative feedback under elevated $\mathrm{CO}_{2}$, Plant Soil, 296, 159-172, doi:10.1007/s11104-007-9306-5, 2007.

Ambus, P., Zechmeister-Boltenstern, S., and Butterbach-Bahl, K.: Sources of nitrous oxide emitted from European forest soils, Biogeosciences, 3, 135-145, doi:10.5194/bg-3-135-2006, 2006.

Averill, C., Turner, B. L., and Finzi, A. C.: Mycorrhiza-mediated competition between plants and decomposers drives soil carbon storage, Nature, 505, 543-545, doi:10.1038/nature12901, 2014.
Baral, B. R., Kuyper, T. W., and Van Groenigen, J. W.: Liebig's law of the minimum applied to a greenhouse gas: alleviation of $\mathrm{P}$ limitation reduces soil $\mathrm{N}_{2} \mathrm{O}$ emission, Plant Soil, 374, 539-548, 2014.

Bardgett, R. D. and Chan, K. F.: Experimental evidence that soil fauna enhance nutrient mineralization and plant nutrient uptake in montane grassland ecosystems, Soil Biol. Biochem., 31, 1007-1014, 1999.

Bardgett, R. D. and Wardle, D. A.: Aboveground-Belowground Linkages: Biotic Interactions, Ecosystem Processes, and Global Change, edited by: Bardgett, R. D. and Wardle, D. A., Oxford University Press, New York, USA, 320 pp., 2010.

Barraclough, D. and Puri, G.: The use of ${ }^{15} \mathrm{~N}$ pool dilution and enrichment to separate the heterotrophic and autotrophic pathways of nitrification, Soil Biol. Biochem., 27, 17-22, 1995.

Barron, A. R., Wurzburger, N., Bellenger, J. P., Wright, S. J., Kraepiel, A. M. L., and Hedin, L. O.: Molybdenum limitation of asymbiotic nitrogen fixation in tropical forest soils, Nat. Geosci., 2, 42-45, doi:10.1038/ngeo366, 2009.

Batterman, S. A., Hedin, L. O., van Breugel, M., Ransijn, J., Craven, D. J., and Hall, J. S.: Key role of symbiotic dinitrogen fixation in tropical forest secondary succession, Nature, 502, 224-227, doi:10.1038/nature12525, 2013a.

Batterman, S. A., Wurzburger, N., and Hedin, L. O.: Nitrogen and phosphorus interact to control tropical symbiotic N2 fixation: a test in Inga punctata, J. Ecol., 101, 1400-1408, doi:10.1111/1365-2745.12138, 2013b.

Beaumont, H. J. E., van Schooten, B., Lens, S. I., Westerhoff, H. V., and van Spanning, R. J. M.: Nitrosomonas europaea expresses a nitric oxide reductase during nitrification, J. Bacteriol., 186, 4417-4421, doi:10.1128/jb.186.13.4417-4421.2004, 2004.

Bergaust, L., Bakken, L. R., and Frostegard, A.: Denitrification regulatory phenotype, a new term for the characterization of denitrifying bacteria, Biochem. Soc. T., 39, 207-212, doi:10.1042/bst0390207, 2011.

Bernal, S., Hedin, L. O., Likens, G. E., Gerber, S., and Buso, D. C.: Complex response of the forest nitrogen cycle to climate change, P. Natl. Acad. Sci. USA, 109, 3406-3411, doi:10.1073/pnas.1121448109, 2012.

Blagodatskaya, E., Littschwager, J., Lauerer, M., and Kuzyakov, Y.: Plant traits regulating $\mathrm{N}$ capture define microbial competition in the rhizosphere, Eur. J. Soil Biol., 61, 41-48, doi:10.1016/j.ejsobi.2014.01.002, 2014.

Blouin, M., Hodson, M. E., Delgado, E. A., Baker, G., Brussaard, L., Butt, K. R., Dai, J., Dendooven, L., Peres, G., Tondoh, J. E., Cluzeau, D., and Brun, J. J.: A review of earthworm impact on soil function and ecosystem services, Eur. J. Soil Sci., 64, 161182, doi:10.1111/ejss.12025, 2013.

Bödeker, I. T. M., Clemmensen, K. E., de Boer, W., Martin, F., Olson, A., and Lindahl, B. D.: Ectomycorrhizal Cortinarius species participate in enzymatic oxidation of humus in northern forest ecosystems, New Phytol., 203, 245-256, doi:10.1111/nph.12791, 2014.

Bouwman, A. F., Beusen, A. H. W., Griffioen, J., Van Groenigen, J. W., Hefting, M. M., Oenema, O., Van Puijenbroek, P., Seitzinger, S., Slomp, C. P., and Stehfest, E.: Global trends and uncertainties in terrestrial denitrification and $\mathrm{N}_{2} \mathrm{O}$ emissions, Philos. T. R. Soc. B , 368, 1621, doi:10.1098/rstb.2013.0112, 2013. 
Boyer, E. W., Goodale, C. L., Jaworski, N. A., and Howarth, R. W.: Anthropogenic nitrogen sources and relationships to riverine nitrogen export in the northeastern USA, Biogeochemistry, 57, 137-169, 2002.

Bradford, M. A.: Good dirt with good friends, Nature, 505, 486487, 2014

Brookshire, E. N. J., Hedin, L. O., Newbold, J. D., Sigman, D. M., and Jackson, J. K.: Sustained losses of bioavailable nitrogen from montane tropical forests, Nat. Geosci., 5, 123-126, doi:10.1038/ngeo1372, 2012

Brown, G. G., Hendrix, P. F., and Beare, M. H.: Earthworms (Lumbricus rubellus) and the fate of ${ }^{15} \mathrm{~N}$ in surface-applied sorghum residues, Soil Biol. Biochem., 30, 1701-1705, 1998.

Burger, M. and Jackson, L. E.: Plant and microbial nitrogen use and turnover: Rapid conversion of nitrate to ammonium in soil with roots, Plant Soil, 266, 289-301, 2004.

Burgin, A. J. and Groffman, P. M.: Soil $\mathrm{O}_{2}$ controls denitrification rates and $\mathrm{N}_{2} \mathrm{O}$ yield in a riparian wetland, J. Geophys. Res.Biogeosci., 117, G01010, doi:10.1029/2011jg001799, 2012.

Burns, D. A., Boyer, E. W., Elliott, E. M., and Kendall, C.: Sources and transformations of nitrate from streams draining varying land uses: Evidence from dual isotope analysis, J. Environ. Qual., 38, 1149-1159, doi:10.2134/jeq2008.0371, 2009.

Casciotti, K. L. and Ward, B. B.: Dissimilatory nitrite reductase genes from autotrophic ammonia-oxidizing bacteria, Appl. Environ. Microbiol., 67, 2213-2221, doi:10.1128/aem.67.5.22132221.2001, 2001

Chapin, F. S., Zavaleta, E. S., Eviner, V. T., Naylor, R. L., Vitousek, P. M., Reynolds, H. L., Hooper, D. U., Lavorel, S., Sala, O. E., Hobbie, S. E., Mack, M. C., and Diaz, S.: Consequences of changing biodiversity, Nature, 405, 234-242, doi:10.1038/35012241, 2000.

Chen, Y., Randerson, J. T., van der Werf, G. R., Morton, D. C., $\mathrm{Mu}, \mathrm{M}$. Q., and Kasibhatla, P. S.: Nitrogen deposition in tropical forests from savanna and deforestation fires, Glob. Change Biol., 16, 2024-2038, doi:10.1111/j.1365-2486.2009.02156.x, 2010.

Cheng, W. X., Parton, W. J., Gonzalez-Meler, M. A., Phillips, R., Asao, S., McNickle, G. G., Brzostek, E., and Jastrow, J. D.: Synthesis and modeling perspectives of rhizosphere priming, New Phytol., 201, 31-44, doi:10.1111/nph.12440, 2014.

Churchland, C. and Grayston, S. J.: Specificity of plant-microbe interactions in the tree mycorrhizosphere biome and consequences for soil C cycling, Front. Microbiol., 5, 261, doi:10.3389/fmicb.2014.00261, 2014.

Cleveland, C., Houlton, B., Neill, C., Reed, S., Townsend, A., and Wang, Y.: Using indirect methods to constrain symbiotic nitrogen fixation rates: a case study from an Amazonian rain forest, Biogeochemistry, 99, 1-13, doi:10.1007/s10533-009-9392-y, 2010.

Comas, L. H., Callahan, H. S., and Midford, P. E.: Patterns in root traits of woody species hosting arbuscular and ectomycorrhizas: implications for the evolution of belowground strategies, Ecol. Evol., 4, 2979-2990, doi:10.1002/ece3.1147, 2014.

Compton, J. E., Harrison, J. A., Dennis, R. L., Greaver, T. L., Hill, B. H., Jordan, S. J., Walker, H., and Campbell, H. V.: Ecosystem services altered by human changes in the nitrogen cycle: a new perspective for US decision making, Ecol. Lett., 14, 804-815, doi:10.1111/j.1461-0248.2011.01631.x, 2011.

Cornelissen, J. H. C., Aerts, R., Cerabolini, B., Werger, M. J. A., and van der Heijden, M. G. A.: Carbon cycling traits of plant species are linked with mycorrhizal strategy, Oecologia, 129, 611-619, doi:10.1007/s004420100752, 2001.

Côrrea, A., Gurevitch, J., Martins-Loucao, M. A., and Cruz, C.: $\mathrm{C}$ allocation to the fungus is not a cost to the plant in ectomycorrhizae, Oikos, 121, 449-463, doi:10.1111/j.16000706.2011.19406.x, 2012.

Davidson, E. A., Hart, S. C., and Firestone, M. K.: Internal cycling of nitrate in soils of a mature coniferous forest, Ecology, 73, 1148-1156, 1992.

Davidson, E. A., David, M. B., Galloway, J. N., Goodale, C. L., Haeuber, R., Harrison, J. A., Howarth, R. W., Jaynes, D. B., Lowrance, R. R., Nolan, B. T., Peel, J. L., Pinder, R. W., Porter, E., Snyder, C. S., Townsend, A. R., and Ward, M. H.: Excess nitrogen in the U.S. environment: Trends, risks, and solutions, Ecology, 15, 1-16, 2012.

Decock, C. and Six, J.: How reliable is the intramolecular distribution of $\mathrm{N}-15$ in $\mathrm{N}_{2} \mathrm{O}$ to source partition $\mathrm{N}_{2} \mathrm{O}$ emitted from soil?, Soil Biol. Biochem., 65, 114-127, doi:10.1016/j.soilbio.2013.05.012, 2013.

de Klein, C. A. M., Shepherd, M. A., and van der Weerden, T. J.: Nitrous oxide emissions from grazed grasslands: interactions between the $\mathrm{N}$ cycle and climate change - a New Zealand case study, Current Opinion in Environmental Sustainability, 9-10, 131-139, doi:10.1016/j.cosust.2014.09.016, 2014.

De-la-Pena, C. and Vivanco, J. M.: Root-Microbe Interactions: The Importance of Protein Secretion, Curr. Proteomics, 7, 265-274, doi:10.2174/157016410793611819, 2010.

DeLuca, T. H., Zackrisson, O., Nilsson, M. C., and Sellstedt, A.: Quantifying nitrogen-fixation in feather moss carpets of boreal forests, Nature, 419, 917-920, doi:10.1038/nature01051, 2002.

Dennis, P. G., Miller, A. J., and Hirsch, P. R.: Are root exudates more important than other sources of rhizodeposits in structuring rhizosphere bacterial communities?, FEMS Microbiol. Ecol., 72, 313-327, doi:10.1111/j.1574-6941.2010.00860.x, 2010.

De Ruiter, P. C., Van Veen, J. A., Moore, J. C., Brussaard, L., and Hunt, H. W.: Calculation of nitrogen mineralization in soil food webs, Plant Soil, 157, 263-273, doi:10.1007/bf00011055, 1993.

De Ruiter, P. C., Neutel, A.-M., and Moore, J. C.: Energetics, Patterns of Interaction Strengths, and Stability in Real Ecosystems, Science, 269, 1257-1260, doi:10.1126/science.269.5228.1257, 1995.

Desloover, J., Roobroeck, D., Heylen, K., Puig, S., Boeckx, P., Verstraete, W., and Boon, N.: Pathway of nitrous oxide consumption in isolated Pseudomonas stutzeri strains under anoxic and oxic conditions, Environ. Microbiol., 16, 3143-3152, doi:10.1111/1462-2920.12404, 2014.

De Vries, F. T. and Bardgett, R. D.: Plant-microbial linkages and ecosystem nitrogen retention: lessons for sustainable agriculture, Front. Ecol. Environ., 10, 425-432, doi:10.1890/110162, 2012.

Díaz, S., Fraser, L. H., Grime, J. P., and Falczuk, V.: The impact of elevated $\mathrm{CO}_{2}$ on plant-herbivore interactions: experimental evidence of moderating effects at the community level, Oecologia, 117, 177-186, doi:10.1007/s004420050646, 1998.

Dickie, I. A., Martinez-Garcia, L. B., Koele, N., Grelet, G. A., Tylianakis, J. M., Peltzer, D. A., and Richardson, S. J.: Mycorrhizas and mycorrhizal fungal communities throughout ecosystem development, Plant Soil, 367, 11-39, doi:10.1007/s11104013-1609-0, 2013. 
Dijkstra, F. A., Morgan, J. A., Blumenthal, D., and Follett, R. F.: Water limitation and plant inter-specific competition reduce rhizosphere-induced $\mathrm{C}$ decomposition and plant N uptake, Soil Biol. Biochem., 42, 1073-1082, doi:10.1016/j.soilbio.2010.02.026, 2010.

Dijkstra, F. A., Carrillo, Y., Pendall, E., and Morgan, J. A.: Rhizosphere priming: a nutrient perspective, Front. Microbiol., 4, 216, doi:10.3389/fmicb.2013.00216, 2013.

Dominguez, J., Bohlen, P. J., and Parmelee, R. W.: Earthworms increase nitrogen leaching to greater soil depths in row crop agroecosystems, Ecosystems, 7, 672-685, doi:10.1007/s10021004-0150-7, 2004.

Drake, H. L. and Horn, M. A.: Earthworms as a transient heaven for terrestrial denitrifying microbes: A review, Eng. Life Sci., 6, 261-265, 2006.

Drake, H. L. and Horn, M. A.: As the Worm Turns: The Earthworm Gut as a Transient Habitat for Soil Microbial Biomes, Annu. Rev. Microbiol., 61, 169-189, 2007.

Drake, J. E., Gallet-Budynek, A., Hofmockel, K. S., Bernhardt, E. S., Billings, S. A., Jackson, R. B., Johnsen, K. S., Lichter, J., McCarthy, H. R., McCormack, M. L., Moore, D. J. P., Oren, R., Palmroth, S., Phillips, R. P., Pippen, J. S., Pritchard, S. G., Treseder, K. K., Schlesinger, W. H., DeLucia, E. H., and Finzi, A. C.: Increases in the flux of carbon belowground stimulate nitrogen uptake and sustain the long-term enhancement of forest productivity under elevated $\mathrm{CO}_{2}$, Ecol. Lett., 14, 349-357, doi:10.1111/j.1461-0248.2011.01593.x, 2011.

Duncan, J. M., Band, L. E., and Groffman, P. M.: Towards closing the watershed nitrogen budget: Spatial and temporal scaling of denitrification, J. Geophys. Res.-Biogeosci., 118, 1-15, doi:10.1002/jgrg.20090, 2013.

Elbert, W., Weber, B., Burrows, S., Steinkamp, J., Buedel, B., Andreae, M. O., and Poeschl, U.: Contribution of cryptogamic covers to the global cycles of carbon and nitrogen, Nat. Geosci., 5, 459-462, doi:10.1038/ngeo1486, 2012.

European Commission - Joint Research Centre: EDGAR 4.2: Emissions database for global atmospheric research, available at: http://edgar.jrc.ec.europa.eu/index.php (last access: 28 October 2014), 2014.

Farías, L., Faundez, J., Fernandez, C., Cornejo, M., Sanhueza, S., and Carrasco, C.: Biological $\mathrm{N}_{2} \mathrm{O}$ fixation in the eastern south pacific ocean and marine cyabobacterialk cultures, Plos One, 8 , e63956, doi:10.1371/journal.pone.0063956, 2013.

Farrar, J., Hawes, M., Jones, D., and Lindow, S.: How roots control the flux of carbon to the rhizosphere, Ecology, 84, 827-837, 2003.

Finzi, A. C., Norby, R. J., Calfapietra, C., Gallet-Budynek, A., Gielen, B., Holmes, W. E., Hoosbeek, M. R., Iversen, C. M., Jackson, R. B., Kubiske, M. E., Ledford, J., Liberloo, M., Oren, R., Polle, A., Pritchard, S., Zak, D. R., Schlesinger, W. H., and Ceulemans, R.: Increases in nitrogen uptake rather than nitrogen-use efficiency support higher rates of temperate forest productivity under elevated $\mathrm{CO}_{2}$, P. Natl. Acad. Sci. USA, 104, 14014-14019, doi:10.1073/pnas.0706518104, 2007.

Frank, D. A. and Groffman, P. M.: Plant rhizospheric N processes: what we don't know and why we should care, Ecology, 90, 15121519, doi:10.1890/08-0789.1, 2009.

Franklin, O., Näsholm, T., Högberg, P., and Högberg, M. N.: Forests trapped in nitrogen limitation - an ecological market perspec- tive on ectomycorrhizal symbiosis, New Phytol., 203, 657-666, doi:10.1111/nph.12840, 2014.

Fry, E. L., Power, S. A., and Manning, P.: Trait-based classification and manipulation of plant functional groups for biodiversityecosystem function experiments, J. Veg. Sci., 25, 248-261, doi:10.1111/jvs.12068, 2014.

Galloway, J. N., Townsend, A. R., Erisman, J. W., Bekunda, M., Cai, Z. C., Freney, J. R., Martinelli, L. A., Seitzinger, S. P., and Sutton, M. A.: Transformation of the nitrogen cycle: Recent trends, questions, and potential solutions, Science, 320, 889-892, doi:10.1126/science.1136674, 2008.

Galloway, J. N., Leach, A. M., Bleeker, A., and Erisman, J. W.: A chronology of human understanding of the nitrogen cycle, Philos. T. R. Soc. B, 368, 11, doi:10.1098/rstb.2013.0120, 2013.

Garbeva, P., Baggs, E. M., and Prosser, J. I.: Phylogeny of nitrite reductase (nirK) and nitric oxide reductase (norB) genes from Nitrosospira species isolated from soil, FEMS Microbiol. Lett., 266, 83-89, doi:10.1111/j.1574-6968.2006.00517.x, 2007.

Garcia-Palacios, P., Maestre, F. T., and Milla, R.: Communityaggregated plant traits interact with soil nutrient heterogeneity to determine ecosystem functioning, Plant Soil, 364, 119-129, doi:10.1007/s11104-012-1349-6, 2013.

Gill, R. A. and Jackson, R. B.: Global patterns of root turnover for terrestrial ecosystems, New Phytol., 147, 13-31, 2000.

Gorham, E.: Biogeochemistry - its origins and development, Biogeochemistry, 13, 199-239, 1991.

Granli, T. and Bøckman, O. C.: Nitrous oxide from agriculture, Norw. J. Agric. Sci., Supplement No. 12, 1-128, 1994.

Grigulis, K., Lavorel, S., Krainer, U., Legay, N., Baxendale, C., Dumont, M., Kastl, E., Arnoldi, C., Bardgett, R. D., Poly, F., Pommier, T., Schloter, M., Tappeiner, U., Bahn, M., and Clément, J.C.: Relative contributions of plant traits and soil microbial properties to mountain grassland ecosystem services, J. Ecol., 101, 47-57, doi:10.1111/1365-2745.12014, 2013.

Grime, J. P.: Benefits of plant diversity to ecosystems: immediate, filter and founder effects, J. Ecol., 86, 902-906, 1998.

Grman, E. and Robinson, T. M. P.: Resource availability and imbalance affect plant-mycorrhizal interactions: a field test of three hypotheses, Ecology, 94, 62-71, 2013.

Groffman, P.: Terrestrial denitrification: challenges and opportunities, Ecol. Proc., 1, 20130112, doi:10.1186/2192-1709-1-11, 2012.

Groffman, P., Butterbach-Bahl, K., Fulweiler, R., Gold, A., Morse, J., Stander, E., Tague, C., Tonitto, C., and Vidon, P.: Challenges to incorporating spatially and temporally explicit phenomena (hotspots and hot moments) in denitrification models, Biogeochemistry, 92, 49-77, 2009.

Groffman, P. M.: Nitrogen balances at ecosystem, landscape, regional and global scales, in: Nitrogen in Agricultural Soils, edited by: Schepers, J. and Raun, W., Soil Science Society of America, Madison, 731-758, 2008.

Groffman, P. M., Altabet, M. A., Bohlke, J. K., Butterbach-Bahl, K., David, M. B., Firestone, M. K., Giblin, A. E., Kana, T. M., Nielsen, L. P., and Voytek, M. A.: Methods for measuring denitrification: Diverse approaches to a difficult problem, Ecol. Appl., 16, 2091-2122, 2006.

Gundale, M. J., Wardle, D. A., and Nilsson, M. C.: The effect of altered macroclimate on $\mathrm{N}$-fixation by boreal feather mosses, Biol. Lett., 8, 805-808, doi:10.1098/rsbl.2012.0429, 2012. 
Hedin, L. O., Brookshire, E. N. J., Menge, D. N. L., and Barron, A. R.: The nitrogen paradox in tropical forest ecosystems, Ann. Rev. Ecol. Evol. S., 40, 613-635, doi:10.1146/annurev.ecolsys.37.091305.110246, 2009.

Heemsbergen, D. A., Berg, M. P., Loreau, M., van Hal, J. R., Faber, J. H., and Verhoef, H. A.: Biodiversity effects on soil processes explained by interspecific functional dissimilarity, Science, 306, 1019-1020, doi:10.1126/science.1101865, 2004.

Hobbie, E. A. and Högberg, P.: Nitrogen isotopes link mycorrhizal fungi and plants to nitrogen dynamics, New Phytol., 196, 367382, doi:10.1111/j.1469-8137.2012.04300.x, 2012.

Hobbie, E. A., Ouimette, A. P., Schuur, E. A. G., Kierstead, D., Trappe, J. M., Bendiksen, K., and Ohenoja, E.: Radiocarbon evidence for the mining of organic nitrogen from soil by mycorrhizal fungi, Biogeochemistry, 114, 381-389, doi:10.1007/s10533-012-9779-z, 2013.

Hodge, A. and Fitter, A. H.: Substantial nitrogen acquisition by arbuscular mycorrhizal fungi from organic material has implications for N cycling, P. Natl. Acad. Sci. USA, 107, 13754-13759, doi:10.1073/pnas.1005874107, 2010.

Hodge, A. and Storer, K.: Arbuscular mycorrhiza and nitrogen: implications for individual plants through to ecosystems, Plant Soil, 386, 1-19, doi:10.1007/s11104-014-2162-1, 2015.

Hooper, A. B.: A nitrite-reducing enzyme from Nitosomonas Europaea - preliminary characterization with hydroxylamine as electron donor, Biochim. Biophys. Acta, 162, 49-65, doi:10.1016/0005-2728(68)90213-2, 1968.

Houlton, B. Z., Sigman, D. M., and Hedin, L. O.: Isotopic evidence for large gaseous nitrogen losses from tropical rainforests, P. Natl. Acad. Sci. USA, 103, 8745-8750, doi:10.1073/pnas.0510185103, 2006.

Howarth, R. W., Billen, G., Swaney, D., Townsend, A., Jaworski, N., Lajtha, K., Downing, J. A., Elmgren, R., Caraco, N., Jordan, T., Berendse, F., Freney, J., Kudeyarov, V., Murdoch, P., and Zhu, Z. L.: Regional nitrogen budgets and riverine N\&P fluxes for the drainages to the North Atlantic Ocean: Natural and human influences, Biogeochemistry, 35, 75-139, 1996.

Huygens, D., Trimmer, M., Rütting, T., Müller, C., Heppell, C. M., Lansdown, K., and Boeckx, P.: Biogeochemical Nitrogen Cycling in Wetland Ecosystems: Nitrogen-15 Isotope Techniques, in: Methods in Biogeochemistry of Wetlands, edited by: DeLaune, R. D., Reddy, K. R., Richardson, C. J., and Megonigal, J. P., Soil Science Society of America, Inc., Madison, Wisconsin, 553-591, 2013.

Ishii, S., Ohno, H., Tsuboi, M., Otsuka, S., and Senoo, K.: Identification and isolation of active $\mathrm{N}_{2} \mathrm{O}$ reducers in rice paddy soil, ISME J., 5, 1936-1945, doi:10.1038/ismej.2011.69, 2011.

Isobe, K. and Ohte, N.: Ecological perspectives on microbes involved in N-cycling, Microbiol. Environ., 29, 4-16, doi:10.1264/jsme2.ME13159, 2014.

Isobe, K., Koba, K., Suwa, Y., Ikutani, J., Kuroiwa, M., Fang, Y., Yoh, M., Mo, J., Otsuka, S., and Senoo, K.: Nitrite transformations in an N-saturated forest soil, Soil Biol. Biochem., 52, 6163, 2012.

Itakura, M., Uchida, Y., Akiyama, H., Hoshino, Y. T., Shimomura, Y., Morimoto, S., Tago, K., Wang, Y., Hayakawa, C., Uetake, Y., Sanchez, C., Eda, S., Hayatsu, M., and Minamisawa, K.: Mitigation of nitrous oxide emissions from soils by Bradyrhi- zobium japonicum inoculation, Nat. Clim. Change, 3, 208-212, doi:10.1038/nclimate1734, 2013.

Jaeger, C. H., Lindow, S. E., Miller, S., Clark, E., and Firestone, M. $\mathrm{K}$.: Mapping of sugar and amino acid availability in soil around roots with bacterial sensors of sucrose and Tryptophan, Appl. Environ. Microbiol., 65, 2685-2690, 1999.

Ji, R. and Brune, A.: Nitrogen mineralization, ammonia accumulation, and emission of gaseous $\mathrm{NH}_{3}$ by soil-feeding termites, Biogeochemistry, 78, 267-283, 2006.

Jones, C. M., Spor, A., Brennan, F. P., Breuil, M. C., Bru, D., Lemanceau, P., Griffiths, B., Hallin, S., and Philippot, L.: Recently indentified microbial guild mediates soil $\mathrm{N}_{2} \mathrm{O}$ sink capacity, Nat. Clim. Change, 4, 801-805, 2014.

Kaiser, C., Koranda, M., Kitzler, B., Fuchslueger, L., Schnecker, J., Schweiger, P., Rasche, F., Zechmeister-Boltenstern, S., Sessitsch, A., and Richter, A.: Belowground carbon allocation by trees drives seasonal patterns of extracellular enzyme activities by altering microbial community composition in a beech forest soil, New Phytol., 187, 843-858, doi:10.1111/j.14698137.2010.03321.x, 2010.

Kaushal, S. S., Groffman, P. M., Band, L. E., Elliott, E. M., Shields, C. A., and Kendall, C.: Tracking nonpoint source nitrogen pollution in human-impacted watersheds, Environ. Sci. Technol., 45, 8225-8232, doi:10.1021/es200779e, 2011.

Kellman, L. and Hillaire-Marcel, C.: Nitrate cycling in streams: using natural abundances of $\mathrm{NO}_{3}^{-}-\mathrm{d}^{15} \mathrm{~N}$ to measure in-situ denitrification, Biogeochemistry, 43, 273-292, 1998.

Keymer, D. P. and Kent, A. D.: Contribution of nitrogen fixation to first year Miscanthus x giganteus, Global Change Biology Bioenergy, 6, 577-586, doi:10.1111/gcbb.12095, 2014.

Kirkham, D. and Bartholomew, W. V.: Equations for following nutrient transformations in soil, utilizing tracer data, Soil Sci. Soc. Am. Proc., 18, 33-34, 1954.

Kirkham, D. and Bartholomew, W. V.: Equations for following nutrient transformations in soil, utilizing tracer data: II, Soil Sci Soc. Am. Proc., 19, 189-192, 1955.

Koele, N., Dickie, I. A., Oleksyn, J., Richardson, S. J., and Reich, P. B.: No globally consistent effect of ectomycorrhizal status on foliar traits, New Phytol., 196, 845-852, doi:10.1111/j.14698137.2012.04297.x, 2012.

Koide, R. T., Sharda, J. N., Herr, J. R., and Malcolm, G. M.: Ectomycorrhizal fungi and the biotrophy-saprotrophy continuum, New Phytol., 178, 230-233, doi:10.1111/j.14698137.2008.02401.x, 2008.

Kool, D. M., Wrage, N., Oenema, O., Dolfing, J., and Van Groenigen, J. W.: Oxygen exchange between (de)nitrification intermediates and $\mathrm{H}_{2} \mathrm{O}$ and its implications for source determination of $\mathrm{N}_{2} \mathrm{O}$ and $\mathrm{NO}_{3}^{-}$: a review, Rapid Commun. Mass Sp., 21, 35693578, 2007.

Kool, D. M., Müller, C., Wrage, N., Oenema, O., and Van Groenigen, J. W.: Oxygen exchange between nitrogen oxides and $\mathrm{H}_{2} \mathrm{O}$ can occur during nitrifier pathways, Soil Biol. Biochem., 41, 1632-1641, doi:10.1016/j.soilbio.2009.05.002, 2009.

Kool, D. M., Wrage, N., Zechmeister-Boltenstern, S., Pfeffer, M., Brus, D. J., Oenema, O., and Van Groenigen, J. W.: Nitrifier denitrification can be a source of $\mathrm{N}_{2} \mathrm{O}$ from soil: a revised approach to the dual isotope labelling method, Eur. J. Soil Sci., 61, 759$772,2010$. 
Kool, D. M., Dolfing, J., Wrage, N., and Van Groenigen, J. W.: Nitrifier denitrification as a distinct and significant source of nitrous oxide from soil, Soil Biol. Biochem., 43, 174-178, doi:10.1016/j.soilbio.2010.09.030, 2011a.

Kool, D. M., Van Groenigen, J. W., and Wrage, N.: Source determination of nitrous oxide based on nitrogen and oxygen isotope tracing: dealing with oxygen exchange, Methods Enzymol., 496, 139-160, 2011b.

Koster, J. R., Well, R., Dittert, K., Giesemann, A., LewickaSzczebak, D., Muhling, K. H., Herrmann, A., Lammel, J., and Senbayram, M.: Soil denitrification potential and its influence on $\mathrm{N}_{2} \mathrm{O}$ reduction and $\mathrm{N}_{2} \mathrm{O}$ isotopomer ratios, Rapid Commun. Mass Sp., 27, 2363-2373, doi:10.1002/rcm.6699, 2013.

Kraft, B., Strous, M., and Tegetmeyer, H. E.: Microbial nitrate respiration - Genes, enzymes and environmental distribution, J. Biotechnol., 155, 104-117, doi:10.1016/j.jbiotec.2010.12.025, 2011.

Kuiper, I., de Deyn, G. B., Thakur, M. P., and van Groenigen, J. W.: Soil invertebrate fauna affect $\mathrm{N}_{2} \mathrm{O}$ emissions from soil, Glob. Change Biol., 19, 2814-2825, doi:10.1111/gcb.12232, 2013.

Kulkarni, M. V., Burgin, A. J., Groffman, P. M., and Yavitt, J. B.: A comparison of denitrification rates as measured using direct flux and ${ }^{15} \mathrm{~N}$ tracer methods in northeastern forest soils, Biogeochemistry, 117, 359-373, 2014.

Kuyper, T. W.: Ectomycorrhiza and the open nitrogen cycle in an afrotropical rainforest, New Phytol., 195, 728-729, doi:10.1111/j.1469-8137.2012.04246.x, 2012.

Kuyper, T. W. and Kiers, E. T.: The danger of mycorrhizal traps?, New Phytol., 203, 352-354, doi:10.1111/nph.12883, 2014.

Kuzyakov, Y. and Cheng, W.: Photosynthesis controls of rhizosphere respiration and organic matter decomposition, Soil Biol. Biochem., 33, 1915-1925, doi:10.1016/s0038-0717(01)00117-1, 2001.

Larmola, T., Leppanen, S. M., Tuittila, E. S., Aarva, M., Merila, P., Fritze, H., and Tiirola, M.: Methanotrophy induces nitrogen fixation during peatland development, P. Natl. Acad. Sci. USA, 111, 734-739, doi:10.1073/pnas.1314284111, 2014.

Lee, S. Y. and Foster, R. C.: Soil Fauna and Soil Structure, Aust. J. Soil Res., 29, 745-775, 1991.

Lewicka-Szczebak, D., Well, R., Koster, J. R., Fuss, R., Senbayram, M., Dittert, K., and Flessa, H.: Experimental determinations of isotopic fractionation factors associated with $\mathrm{N}_{2} \mathrm{O}$ production and reduction during denitrification in soils, Geochim. Cosmochim. Ac., 134, 55-73, doi:10.1016/j.gca.2014.03.010, 2014.

Liiri, M., Ilmarinen, K., and Setälä, H.: Variable impacts of enchytraeid worms and ectomycorrhizal fungi on plant growth in raw humus soil treated with wood ash, Appl. Soil Ecol., 35, 174-183, 2007.

Lindahl, B. D., Ihrmark, K., Boberg, J., Trumbore, S. E., Hogberg, P., Stenlid, J., and Finlay, R. D.: Spatial separation of litter decomposition and mycorrhizal nitrogen uptake in a boreal forest, New Phytol., 173, 611-620, doi:10.1111/j.14698137.2006.01936.x, 2007.

Loreau, M.: Ecosystem development explained by competition within and between material cycles, P. R. Soc. B, 265, 33-38, doi:10.1098/rspb.1998.0260, 1998.

Lowrance, R., Altier, L. S., Newbold, J. D., Schnabel, R. R., Groffman, P. M., Denver, J. M., Correll, D. L., Gilliam, J. W., Robinson, J. L., Brinsfield, R. B., Staver, K. W., Lucas, W., and Todd,
A. H.: Water quality functions of riparian forest buffers in Chesapeake Bay watersheds, Environ. Manage., 21, 687-712, 1997.

Lubbers, I. M., van Groenigen, K. J., Fonte, S. J., Six, J., Brussaard, L., and van Groenigen, J. W.: Greenhouse-gas emissions from soils increased by earthworms, Nat. Clim. Change, 3, 187-194, 2013.

Luo, Y., Su, B., Currie, W. S., Dukes, J. S., Finzi, A. C., Hartwig, U., Hungate, B., McMurtrie, R. E., Oren, R., Parton, W. J., Pataki, D. E., Shaw, M. R., Zak, D. R., and Field, C. B.: Progressive nitrogen limitation of ecosystem responses to rising atmospheric carbon dioxide, Bioscience, 54, 731-739, doi:10.1641/00063568(2004)054[0731:pnloer]2.0.co;2, 2004.

Luo, Y., Melillo, J., Niu, S., Beier, C., Clark, J. S., Classen, A. T., Davidson, E., Dukes, J. S., Evans, R. D., Field, C. B., Czimczik, C. I., Keller, M., Kimball, B. A., Kueppers, L. M., Norby, R. J., Pelini, S. L., Pendall, E., Rastetter, E., Six, J., Smith, M., Tjoelker, M. G., and Torn, M. S.: Coordinated approaches to quantify long-term ecosystem dynamics in response to global change, Global Change Biol., 17, 843-854, doi:10.1111/j.13652486.2010.02265.x, 2011.

Majumdar, D.: Biogeochemistry of $\mathrm{N}_{2} \mathrm{O}$ Uptake and Consumption in Submerged Soils and Rice Fields and Implications in Climate Change, Crit. Rev. Env. Sci. Tec., 43, 2653-2684, doi:10.1080/10643389.2012.694332, 2013.

Mania, D., Heylen, K., Van Spanning, R. J., and Frostegard, Å.: The nitrate-ammonifying and nosZ carrying bacterium Bacillus vireti is a potent source and sink for nitric and nitrous oxide under high nitrate conditions, Environ. Microbiol., 16, 3196-3210, doi:10.1111/1462-2920.12478, 2014.

Matson, P. A., McDowell, W. H., Townsend, A. R., and Vitousek, P. M.: The globalization of $\mathrm{N}$ deposition: ecosystem consequences in tropical environments, Biogeochemistry, 46, 67-83, doi:10.1023/a:1006152112852, 1999.

Mayer, P. M., Reynolds, S. K., McCutchen, M. D., and Canfield, T. J.: Meta-analysis of nitrogen removal in riparian buffers, J. Environ. Qual., 36, 1172-1180, doi:10.2134/jeq2006.0462, 2007.

Midgley, M. G. and Phillips, R. P.: Mycorrhizal associations of dominant trees influence nitrate leaching responses to $\mathrm{N}$ deposition, Biogeochemistry, 117, 241-253, doi:10.1007/s10533-0139931-4, 2014.

Mikola, J. and Setälä, H.: No evidence of trophic cascades in an experimental microbial-based soil food web, Ecology, 79, 153164, doi:10.2307/176871, 1998.

Moorshammer, M., Wanek, W., Hämmerle, I., Fuchslueger, L., Hofmhansl, F., Knoltsch, A., Schnecker, J., Takriti, M., Watzka, M., Wild, B., Keiblinger, K. M., Zechmeister-Boltenstern, S., and Richter, A.: Adjustment of microbial nitrogen use efficiency to carbon:nitrogen imbalance regulates soil nitrogen cycling, Nat. Commun., 5, 3694, doi:10.1038/ncomms4694, 2014.

Morse, J. L., Werner, S. F., Gillen, C., Bailey, S. W., McGuire, K. J., and Groffman, P. M.: Searching for biogeochemical hotspots in three dimensions: Soil C and N cycling in hydropedologic units in a northern hardwood forest, J. Geophys. Res.-Biogeosci., 119, 1596-1607, doi:10.1002/2013JG002589, 2014.

Morse, J. L., Durán, J., Beall, F., Enanga, E., Creed, I. F., Fernandez, I. J., and Groffman, P. M.: Soil denitrification fluxes from three northeastern North American forests ranging in nitrogen availability, Oecologia, 177, 17-27, doi:10.1007/s00442-014-3117-1, 2015. 
Mosier, A. R., Duxbury, J. M., Freney, J. R., Heinemeyer, O., and Minami, K.: Assessing and mitigating $\mathrm{N}_{2} \mathrm{O}$ emissions from agricultural soils, Clim. Change, 40, 7-38, doi:10.1023/a:1005386614431, 1998

Mulder, A., Vandegraaf, A. A., Robertson, L. A., and Kuenen, J. G.: Anaerobic ammonium oxidation discovered in a denitrifying fluidized bed reactor, FEMS Microbiol. Ecol., 16, 177-183, doi:10.1111/j.1574-6941.1995.tb00281.x, 1995.

Müller, C., Laughlin, R. J., Spott, O., and Rütting, T.: Quantification of $\mathrm{N}_{2} \mathrm{O}$ emission pathways via a ${ }^{15} \mathrm{~N}$ tracing model, Soil Biol. Biochem., 72, 44-54, 2014

Myrold, D. D. and Tiedje, J. M.: Simultaneous estimation of several nitrogen cycle rates using ${ }^{15} \mathrm{~N}$ : theory and application, Soil Biol. Biochem., 18, 559-568, 1986.

Näsholm, T., Högberg, P., Franklin, O., Metcalfe, D., Keel, S. G., Campbell, C., Hurry, V., Linder, S., and Högberg, M. N.: Are ectomycorrhizal fungi alleviating or aggravating nitrogen limitation of tree growth in boreal forests?, New Phytol., 198, 214-221, doi:10.1111/nph.12139, 2013.

Nebert, L. D., Bloem, J., Lubbers, I. M., and Van Groenigen, J. W.: Association of earthworm - denitrifier interactions with increased emissions of nitrous oxide from soil mesocosms amended with crop residue, Appl. Environ. Microbiol., 77, 40974104, 2011.

Nguyen, C.: Rhizodeposition of organic C by plants: mechanisms and controls, Agronomie, 23, 375-396, doi:10.1051/agro:2003011, 2003.

Orellana, L. H., Rodriguez-R, L. M., Higgins, S., Chee-Sanford, J. C., Sanford, R. A., Ritalahti, K. M., Loffler, F. E., and Konstantinidis, K. T.: Detecting nitrous oxide reductase (nosZ) genes in soil metagenomes: methods development and implications for the nitrogen cycle, Mbio, 5, doi:10.1128/mBio.01193-14, 2014.

Orwin, K. H., Buckland, S. M., Johnson, D., Turner, B. L., Smart, S., Oakley, S., and Bardgett, R. D.: Linkages of plant traits to soil properties and the functioning of temperate grassland, J. Ecol., 98, 1074-1083, doi:10.1111/j.1365-2745.2010.01679.x, 2010.

Ostrom, N. E. and Ostrom, P. H.: The isotopomers of nitrous oxide: analytical considerations and application to resolution of microbial production pathways, in: Handbook of environmental isotope geochemistry, edited by: Baskaran, M., Springer-Verlag, Berlin, 453-476, 2011.

Parkin, T. B. and Berry, E. C.: Microbial nitrogen transformations in earthworm burrows, Soil Biol. Biochem., 31, 1765-1771, 1999.

Paterson, E.: Importance of rhizodeposition in the coupling of plant and microbial productivity, Eur. J. Soil Sci., 54, 741-750, 2003.

Pausch, J., Tian, J., Riederer, M., and Kuzyakov, Y.: Estimation of rhizodeposition at field scale: upscaling of a C-14 labeling study, Plant Soil, 364, 273-285, doi:10.1007/s11104-012-13638, 2013a.

Pausch, J., Zhu, B., Kuzyakov, Y., and Cheng, W.: Plant inter-species effects on rhizosphere priming of soil organic matter decomposition, Soil Biol. Biochem., 57, 91-99, doi:10.1016/j.soilbio.2012.08.029, 2013 b.

Philippot, L., Hallin, S., Borjesson, G., and Baggs, E. M.: Biochemical cycling in the rhizosphere having an impact on global change, Plant Soil, 321, 61-81, doi:10.1007/s11104-008-9796-9, 2009.

Phillips, R. P., Finzi, A. C., and Bernhardt, E. S.: Enhanced root exudation induces microbial feedbacks to $\mathrm{N}$ cycling in a pine forest under long-term $\mathrm{CO}_{2}$ fumigation, Ecol. Lett., 14, 187-194, doi:10.1111/j.1461-0248.2010.01570.x, 2011.

Phillips, R. P., Meier, I. C., Bernhardt, E. S., Grandy, A. S., Wickings, K., and Finzi, A. C.: Roots and fungi accelerate carbon and nitrogen cycling in forests exposed to elevated $\mathrm{CO}_{2}$, Ecol. Lett., 15, 1042-1049, doi:10.1111/j.1461-0248.2012.01827.x, 2012.

Phillips, R. P., Brzostek, E., and Midgley, M. G.: The mycorrhizalassociated nutrient economy: a new framework for predicting carbon-nutrient couplings in temperate forests, New Phytol., 199, 41-51, doi:10.1111/nph.12221, 2013.

Pomowski, A., Zumft, W. G., Kroneck, P. M. H., and Einsle, O.: $\mathrm{N}_{2} \mathrm{O}$ binding at a $4 \mathrm{Cu}: 2 \mathrm{~S}$ copper-sulphur cluster in nitrous oxide reductase, Nature, 477, 234-237, doi:10.1038/nature10332, 2011.

Postma-Blaauw, M. B., Bloem, J., Faber, J. H., Van Groenigen, J. W., De Goede, R. G. M., and Brussaard, L.: Earthworm species composition affects the soil bacterial community and net nitrogen mineralization, Pedobiologia, 50, 243-256, 2006.

Poth, M. and Focht, D. D.: N-15 kinetic - analysis of $\mathrm{N}_{2} \mathrm{O}$ production by Nitrosomonas Europaea - an examination of nitrifier denitrification, Appl. Environ. Microbiol., 49, 1134-1141, 1985.

Rantalainen, M.-L., Fritze, H., Haimi, J., Kiikkilä, O., Pennanen, T., and Setälä, H.: Do enchytraeid worms and habitat corridors facilitate the colonisation of habitat patches by soil microbes?, Biol. Fertility Soils, 39, 200-208, doi:10.1007/s00374003-0687-1, 2004.

Read, D. J.: Mycorrhizas in ecosystems, Experientia, 47, 376-391, doi:10.1007/bf01972080, 1991

Read, D. J. and Perez-Moreno, J.: Mycorrhizas and nutrient cycling in ecosystems - a journey towards relevance?, New Phytol., 157, 475-492, doi:10.1046/j.1469-8137.2003.00704.x, 2003.

Reed, S. C., Cleveland, C. C., and Townsend, A. R.: Functional ecology of free-living nitrogen fixation: A contemporary perspective, Annu. Rev. Ecol. Evol. S., 42, 489-512, doi:10.1146/annurev-ecolsys-102710-145034, 2011.

Reich, P. B.: The world-wide "fast-slow" plant economics spectrum: a traits manifesto, J. Ecol., 102, 275-301, 2014.

Rineau, F., Shah, F., Smits, M. M., Persson, P., Johansson, T., Carleer, R., Troein, C., and Tunlid, A.: Carbon availability triggers the decomposition of plant litter and assimilation of nitrogen by an ectomycorrhizal fungus, ISME J., 7, 2010-2022, doi:10.1038/ismej.2013.91, 2013.

Ritchie, G. A. F. and Nicholas, D. J.: Identification of sources of nitrous-oxide produced by oxidate and reductive processes in $\mathrm{Ni}$ trosomonas Europaea, Biochem. J., 126, 1181-1191, 1972.

Rizhiya, E., Bertora, C., Van Vliet, P. C. J., Kuikman, P. J., Faber, J. H., and Van Groenigen, J. W.: Earthworm activity as a determinant for $\mathrm{N}_{2} \mathrm{O}$ emission from crop residue, Soil Biol. Biochem., 39, 2058-2069, 2007.

Rütting, T. and Müller, C.: Process-specific analysis of nitrite dynamics in a permanent grassland soil by using a Monte Carlo sampling technique, Eur. J. Soil Sci., 59, 208-215, 2008.

Rütting, T., Huygens, D., Müller, C., Van Cleemput, O., Godoy, R., and Boeckx, P.: Functional role of DNRA and nitrite reduction in a pristine south Chilean Nothofagus forest, Biogeochemistry, 90, 243-258, 2008.

Rütting, T., Boeckx, P., Müller, C., and Klemedtsson, L.: Assessment of the importance of dissimilatory nitrate reduction to am- 
monium for the terrestrial nitrogen cycle, Biogeosciences, 8 , 1779-1791, doi:10.5194/bg-8-1779-2011, 2011a.

Rütting, T., Huygens, D., Staelens, J., Müller, C., and Boeckx, P.: Advances in ${ }^{15} \mathrm{~N}$ tracing experiments: new labelling and data analysis approaches, Biochem. Soc. T., 39, 279-283, $2011 \mathrm{~b}$.

Sanford, R. A., Wagner, D. D., Wu, Q. Z., Chee-Sanford, J. C., Thomas, S. H., Cruz-Garcia, C., Rodriguez, G., Massol-Deya, A., Krishnani, K. K., Ritalahti, K. M., Nissen, S., Konstantinidis, K. T., and Loffler, F. E.: Unexpected nondenitrifier nitrous oxide reductase gene diversity and abundance in soils, P. Natl. Acad. Sci. USA, 109, 19709-19714, doi:10.1073/pnas.1211238109, 2012.

Sawayama, S.: Possibility of anoxic ferric ammonium oxidation, J. Biosci. Bioeng., 101, 70-72, 2006.

Schimel, J.: Assumptions and errors in the ${ }^{15} \mathrm{NH}_{4}^{+}$pool dilution technique for measuring mineralization and immobilization, Soil Biol. Biochem., 28, 827-828, 1996.

Schimel, J. P. and Bennett, J.: Nitrogen mineralization: challenges of a changing paradigm, Ecology, 85, 591-602, 2004.

Schlesinger, W. H.: An estimate of the global sink for nitrous oxide in soils, Glob. Change Biol., 19, 2929-2931, doi:10.1111/gcb.12239, 2013.

Schmidt, I., van Spanning, R. J. M., and Jetten, M. S. M.: Denitrification and ammonia oxidation by Nitrosomonas europaea wildtype, and NirK- and NorB-deficient mutants, Microbiology-Sgm, 150, 4107-4114, doi:10.1099/mic.0.27382-0, 2004.

Seitzinger, S., Harrison, J. A., Bohlke, J. K., Bouwman, A. F., Lowrance, R., Peterson, B., Tobias, C., and Van Drecht, G.: Denitrification across landscapes and waterscapes: A synthesis, Ecol. Appl., 16, 2064-2090, 2006.

Shaw, L. J., Nicol, G. W., Smith, Z., Fear, J., Prosser, J. I., and Baggs, E. M.: Nitrosospira spp. can produce nitrous oxide via a nitrifier denitrification pathway, Environ. Microbiol., 8, 214222, doi:10.1111/j.1462-2920.2005.00882.x, 2006.

Shipitalo, M. J. and Le Bayon, R. C.: Quantifying the Effects of Earthworms on Soil Aggregation and Porosity, in: Earthworm Ecology, edited by: Edwards, C. A., CRC Press LLC, Boca Raton, FL, 183-200, 2004.

Simon, J.: Enzymology and bioenergetics of respiratory nitrite ammonification, FEMS Microbiol. Rev., 26, 285-309, doi:10.1111/j.1574-6976.2002.tb00616.x, 2002.

Simon, J. and Klotz, M. G.: Diversity and evolution of bioenergetic systems involved in microbial nitrogen compound transformations, BBA-Bioenergetics, 1827, 114-135, doi:10.1016/j.bbabio.2012.07.005, 2013.

Simon, J., Einsle, O., Kroneck, P. M. H., and Zumft, W. G.: The unprecedented nos gene cluster of Wolinella succinogenes encodes a novel respiratory electron transfer pathway to cytochrome c nitrous oxide reductase, FEBS Lett., 569, 7-12, doi:10.1016/j.febslet.2004.05.060, 2004.

Spott, O., Russow, R., and Stange, C. F.: Formation of hybrid $\mathrm{N}_{2} \mathrm{O}$ and hybrid $\mathrm{N}_{2}$ due to codenitrification: First review of a barely considered process of microbially mediated N-nitrosation, Soil Biol. Biochem., 43, 1995-2011, doi:10.1016/j.soilbio.2011.06.014, 2011.

Stange, C. F., Spott, O., and Müller, C.: An inverse abundance approach to separate soil nitrogen pools and gaseous nitrogen fluxes into fractions related to ammonium, nitrate and soil organic nitrogen, Eur. J. Soil Sci., 60, 907-915, 2009.
Stange, C. F., Spott, O., and Russow, R.: Analysis of the coexisting pathways for $\mathrm{NO}$ and $\mathrm{N}_{2} \mathrm{O}$ formation in Chernozem using the ${ }^{15} \mathrm{~N}$-tracer SimKIM-Advanced model, Isotop. Environm. Health Stud., 49, 503-519, 2013.

Stevens, R. J., Laughlin, R. J., Burns, L. C., Arah, J. R. M., and Hood, R. C.: Measuring the contributions of nitrification and denitrification to the flux of nitrous oxide from soil, Soil Biol. Biochem., 29, 139-151, 1997.

Stocker, T. E., Qin, D., Plattner, G.-K., Tignor, M., Allen, S. K., Boschung, J., Nauels, A., Xia, Y., Bex, V., and Midgley, P. M.: Climate Change 2013: The physical science basis. Contribution of working group I to the fifth assessment report of the Intergovernmental Panel on Climate Change, Cambridge University Press, Cambridge, UK, 2013.

Sullivan, B. W., Smith, W. K., Townsend, A. R., Nasto, M. K., Reed, S. C., Chazdon, R. L., and Cleveland, C. C.: Spatially robust estimates of biological nitrogen $(\mathrm{N})$ fixation imply substantial human alteration of the tropical $\mathrm{N}$ cycle, P. Natl. Acad. Sci. USA, 111, 8101-8106, doi:10.1073/pnas.1320646111, 2014.

Sutka, R. L., Ostrom, N. E., Ostrom, P. H., Breznak, J. A., Gandhi, H., Pitt, A. J., and Li, F.: Distinguishing nitrous oxide production from nitrification and denitrification on the basis of isotopomer abundances, Appl. Environ. Microbiol., 72, 638-644, doi:10.1128/aem.72.1.638-644.2006, 2006.

Swerts, M., Uytterhoeven, G., Merckx, R., and Vlassak, K.: Semicontinuous measurement of soil atmosphere gases with gas-flow soil core method, Soil Sci. Soc. Am. J., 59, 1336-1342, 1995.

Talbot, J. M. and Treseder, K. K.: Controls over mycorrhizal uptake of organic nitrogen, Pedobiologia, 53, 169-179, doi:10.1016/j.pedobi.2009.12.001, 2010.

Talbot, J. M., Allison, S. D., and Treseder, K. K.: Decomposers in disguise: mycorrhizal fungi as regulators of soil $\mathrm{C}$ dynamics in ecosystems under global change, Funct. Ecol., 22, 955-963, doi:10.1111/j.1365-2435.2008.01402.x, 2008.

Taylor, A. E., Vajrala, N., Giguere, A. T., Gitelman, A. I., Arp, D. J., Myrold, D. D., Sayavedra-Soto, L., and Bottomley, P. J.: Use of Aliphatic n-Alkynes To Discriminate Soil Nitrification Activities of Ammonia-Oxidizing Thaumarchaea and Bacteria, Appl. Environ. Microbiol., 79, 6544-6551, doi:10.1128/aem.01928-13, 2013.

Tedersoo, L., Naadel, T., Bahram, M., Pritsch, K., Buegger, F., Leal, M., Koljalg, U., and Poldmaa, K.: Enzymatic activities and stable isotope patterns of ectomycorrhizal fungi in relation to phylogeny and exploration types in an afrotropical rain forest, New Phytol., 195, 832-843, doi:10.1111/j.1469-8137.2012.04217.x, 2012.

Thakur, M. P., van Groenigen, J. W., Kuiper, I., and De Deyn, G. B.: Interactions between microbial-feeding and predatory soil fauna trigger $\mathrm{N}_{2} \mathrm{O}$ emissions, Soil Biol. Biochem., 70, 256-262, doi:10.1016/j.soilbio.2013.12.020, 2014.

Thomas, R. Q., Canham, C. D., Weathers, K. C., and Goodale, C. L.: Increased tree carbon storage in response to nitrogen deposition in the US, Nat. Geosci., 3, 13-17, doi:10.1038/ngeo721, 2010.

Tiedje, J. M.: Ecology of denitrification and dissimilatory nitrate reduction to ammonium, in: Biology of anaerobic microorganisms, edited by: Zehnder, A. J. B., Wiley, New York, 179-244, 1988.

Tilsner, J., Wrage, N., Lauf, J., and Gebauer, G.: Emission of gaseous nitrogen oxides from an extensively managed grassland in NE Bavaria, Germany - II. Stable iso- 
tope natural abundance of $\mathrm{N}_{2} \mathrm{O}$, Biogeochemistry, 63, 249-267, doi:10.1023/a:1023316315550, 2003.

Topoliantz, S., Ponge, J.-F., and Viaux, P.: Earthworm and enchytraeid activity under different arable farming systems, as exemplified by biogenic structures, Plant Soil, 225, 39-51, doi:10.1023/a:1026537632468, 2000.

Van Breemen, N., Boyer, E. W., Goodale, C. L., Jaworski, N. A., Paustian, K., Seitzinger, S. P., Lajtha, K., Mayer, B., Van Dam, D., Howarth, R. W., Nadelhoffer, K. J., Eve, M., and Billen, G.: Where did all the nitrogen go? Fate of nitrogen inputs to large watersheds in the northeastern USA, Biogeochemistry, 57, 267293, 2002.

Van der Krift, T. A. J., Kuikman, P. J., Moller, F., and Berendse, F.: Plant species and nutritional-mediated control over rhizodeposition and root decomposition, Plant Soil, 228, 191-200, doi:10.1023/a:1004834128220, 2001.

Van Groenigen, J. W., Lubbers, I. M., Vos, H. M. J., Brown, G. G., De Deyn, G. B., and Van Groenigen, K. J.: Earthworms increase plant production: a meta-analysis, Sci. Rep., 4, 6365, doi:10.1038/srep06365, 2014.

Van Groenigen, K. J., Six, J., Hungate, B. A., de Graaff, M. A., Van Breemen, N., and Van Kessel, C.: Element interactions limit soil carbon storage, P. Natl. Acad. Sci. USA, 103, 6571-6574, doi:10.1073/pnas.0509038103, 2006.

Van Vliet, P. C. J., Beare, M. H., Coleman, D. C., and Hendrix, P. F.: Effects of enchytraeids (Annelida: Oligochaeta) on soil carbon and nitrogen dynamics in laboratory incubations, Appl. Soil Ecol., 25, 147-160, 2004.

Verbaendert, I., Hoefman, S., Boeckx, P., Boon, N., and De Vos, P.: Primers for overlooked nirK, qnorB, and nosZ genes of thermophilic Gram-positive denitrifiers, FEMS Microbiol. Ecol., 89, 162-180, doi:10.1111/1574-6941.12346, 2014.

Veresoglou, S. D., Chen, B. D., and Rillig, M. C.: Arbuscular mycorrhiza and soil nitrogen cycling, Soil Biol. Biochem., 46, 53-62, doi:10.1016/j.soilbio.2011.11.018, 2012.

Verhoef, H. A. and Brussaard, L.: Decomposition and nitrogen mineralization in natural and agroecosystems: the contribution of soil animals, Biogeochemistry, 11, 175-211, doi:10.1007/bf00004496, 1990.

Vidon, P. and Hill, A. R.: Denitrification and patterns of electron donors and acceptors in eight riparian zones with contrasting hydrogeology, Biogeochemistry, 71, 259-283, 2004.

Vieten, B., Conen, F., Seth, B., and Alewell, C.: The fate of $\mathrm{N}_{2} \mathrm{O}$ consumed in soils, Biogeosciences, 5, 129-132, doi:10.5194/bg5-129-2008, 2008.

Vitousek, P. M., Menge, D. N. L., Reed, S. C., and Cleveland, C. C.: Biological nitrogen fixation: rates, patterns and ecological controls in terrestrial ecosystems, P. T. Roy. Soc. B, 368, 20130119 , doi:10.1098/rstb.2013.0119, 2013.

Walter, M. T., Walter, M. F., Brooks, E. S., Steenhuis, T. S., Boll, J., and Weiler, K.: Hydrologically sensitive areas: Variable source area hydrology implications for water quality risk assessment, $\mathrm{J}$. Soil Water Conserv., 55, 277-284, 2000.

Wanek, W., Mooshammer, M., Blöchl, A., Hanreich, A., and Richter, A.: Determination of gross rates of amino acid production and immobilization in decomposing leaf litter by a novel ${ }^{15} \mathrm{~N}$ isotope pool dilution technique, Soil Biol. Biochem., 42, 1293-1302, 2010.
Wang, R., Willibald, G., Feng, Q., Zheng, X., Liao, T., Brüggemann, N., and Butterbach-Bahl, K.: Measurement of $\mathrm{N}_{2}, \mathrm{~N}_{2} \mathrm{O}$, NO, and $\mathrm{CO}_{2}$ emissions from soil with the gas-flow-soil-core technique, Environ. Sci. Technol., 45, 6066-6072, doi:10.1021/es1036578, 2011.

Wardle, D. A.: The influence of biotic interactions on soil biodiversity, Ecol. Lett., 9, 870-886, doi:10.1111/j.14610248.2006.00931.x, 2006.

Wardle, D. A., Bardgett, R. D., Klironomos, J. N., Setala, H., van der Putten, W. H., and Wall, D. H.: Ecological linkages between aboveground and belowground biota, Science, 304, 1629-1633, 2004.

Wassenaar, L. I.: Evaluation of the origin and fate of nitrate in the Abbbotsford Aquifer using isotopes of ${ }^{15} \mathrm{~N}$ and ${ }^{18} \mathrm{O}$ in $\mathrm{NO}_{3}^{-}$, Appl. Geochem., 10, 391-405, 1995.

Webster, E. A. and Hopkins, D. W.: Contributions from different microbial processes to $\mathrm{N}_{2} \mathrm{O}$ emission from soil under different moisture regimes, Biol. Fertility Soils, 22, 331-335, doi:10.1007/s003740050120, 1996.

Wedin, D. A. and Tilman, D.: Species effects on nitrogen cycling: a test with perennial grasses, Oecologia, 84, 433-441, 1990.

Well, R. and Butterbach-Bahl, K.: Comments on "A test of a fieldbased N-15-nitrous oxide pool dilution technique to measure gross $\mathrm{N}_{2} \mathrm{O}$ production in soil" by Yang et al. (2011), Global Change Biology, 17, 3577-3588, Global Change Biol., 19, 133 135, doi:10.1111/gcb.12005, 2013.

Werner, C., Butterbach-Bahl, K., Haas, E., Hickler, T., and Kiese, R.: A global inventory of $\mathrm{N}_{2} \mathrm{O}$ emissions from tropical rainforest soils using a detailed biogeochemical model, Global Biogeochem. Cy., 21, doi:10.1029/2006gb002909, 2007.

Werner, S. F., Driscoll, C. T., Groffman, P. M., and Yavitt, J. B.: Landscape patterns of soil oxygen and atmospheric greenhouse gases in a northern hardwood forest landscape, Biogeosciences Discuss., 8, 10859-10893, doi:10.5194/bgd-8-108592011, 2011.

Whalen, J. K. and Sampedro, L.: Soil Ecology \& Management, Cambridge University Press, Cambridge, UK, 2010.

Whiteside, M. D., Garcia, M. O., and Treseder, K. K.: Amino acid uptake in arbuscular mycorrhizal plants, Plos One, 7, e47643, doi:10.1371/journal.pone.0047643, 2012.

Woli, K. P., David, M. B., Cooke, R. A., McIsaac, G. F., and Mitchell, C. A.: Nitrogen balance in and export from agricultural fields associated with controlled drainage systems and denitrifying bioreactors, Ecol. Eng., 36, 1558-1566, doi:10.1016/j.ecoleng.2010.04.024, 2010.

Wrage, N., Velthof, G. L., Van Beusichem, M. L., and Oenema, O.: Role of nitrifier denitrification in the production of nitrous oxide, Soil Biol. Biochem., 33, 1723-1732, 2001.

Wrage, N., Velthof, G. L., Laanbroek, H. J., and Oenema, O.: Nitrous oxide production in grassland soils: assessing the contribution of nitrifier denitrification, Soil Biol. Biochem., 36, 229-236, doi:10.1016/j.soilbio.2003.09.009, 2004a.

Wrage, N., Velthof, G. L., Oenema, O., and Laanbroek, H. J.: Acetylene and oxygen as inhibitors of nitrous oxide production in Nitrosomonas europaea and Nitrosospira briensis: a cautionary tale, FEMS Microbiol. Ecol., 47, 13-18, doi:10.1016/s01686496(03)00220-4, 2004b.

Wrage, N., Van Groenigen, J. W., Oenema, O., and Baggs, E. M.: A novel dual-isotope labeling method for distinguishing between 
soil sources of $\mathrm{N}_{2} \mathrm{O}$, Rapid Commun. Mass Sp., 19, 3298-3306, 2005.

Wu, T. H.: Can ectomycorrhizal fungi circumvent the nitrogen mineralization for plant nutrition in temperate forest ecosystems?, Soil Biol. Biochem., 43, 1109-1117, doi:10.1016/j.soilbio.2011.02.003, 2011.

Wurzburger, N., Bellenger, J. P., Kraepiel, A. M. L., and Hedin, L. O.: Molybdenum and phosphorus interact to constrain asymbiotic nitrogen fixation in tropical forests, Plos One, 7, e33710, doi:10.1371/journal.pone.0033710, 2012.

Yanai, R. D., Vadeboncoeur, M. A., Hamburg, S. P., Arthur, M. A., Fuss, C. B., Groffman, P. M., Siccama, T. G., and Driscoll, C. T.: From missing source to missing sink: Long-term changes in the nitrogen budget of a northern hardwood forest, Environ. Sci. Technol., 47, 11440-11448, doi:10.1021/es4025723, 2013.

Yang, W. D. H., Teh, Y. A., and Silver, W. L.: A test of a fieldbased ${ }^{15} \mathrm{~N}$-nitrous oxide pool dilution technique to measure gross $\mathrm{N}_{2} \mathrm{O}$ production in soil, Glob. Change Biol., 17, 3577-3588, doi:10.1111/j.1365-2486.2011.02481.x, 2011.

Yang, W. H. and Silver, W. L.: Application of the $\mathrm{N}_{2}$ /Ar technique to measuring soil-atmosphere $\mathrm{N}_{2}$ fluxes, Rapid Commun. Mass Sp., 26, 449-459, doi:10.1002/rcm.6124, 2012.

Yang, W. H., McDowell, A. C., Brooks, P. D., and Silver, W. L.: New high precision approach for measuring ${ }^{15} \mathrm{~N}-\mathrm{N}_{2}$ gas fluxes from terrestrial ecosystems, Soil Biol. Biochem., 69, 234-241, doi:10.1016/j.soilbio.2013.11.009, 2014.
Yano, M., Toyoda, S., Tokida, T., Hayashi, K., Hasegawa, T., Makabe, A., Koba, K., and Yoshida, N.: Isotopomer analysis of production, consumption and soil-to-atmosphere emission processes of $\mathrm{N}_{2} \mathrm{O}$ at the beginning of paddy field irrigation, Soil Biol. Biochem., 70, 66-78, doi:10.1016/j.soilbio.2013.11.026, 2014.

Yuan, Z. Y. and Chen, H. Y. H.: Fine root biomass, production, turnover rates, and nutrient contents in boreal forest ecosystems in relation to species, climate, fertility, and stand age: literature review and meta-analyses, Crit. Rev. Plant Sci., 29, 204-221, doi:10.1080/07352689.2010.483579, 2010.

Zak, D. R., Holmes, W. E., Finzi, A. C., Norby, R. J., and Schlesinger, W. H.: Soil nitrogen cycling under elevated $\mathrm{CO}_{2}$ : A synthesis of forest face experiments, Ecol. Appl., 13, 15081514, 2003.

Zhu, X., Burger, M., Doane, T. A., and Horwath, W. R.: Ammonia oxidation pathways and nitrifier denitrification are significant sources of $\mathrm{N}_{2} \mathrm{O}$ and $\mathrm{NO}$ under low oxygen availability, P. Natl. Acad. Sci. USA, 110, 6328-6333, doi:10.1073/pnas.1219993110, 2013. 